NBER WORKING PAPER SERIES

\title{
FROM HERMIT KINGDOM TO MIRACLE ON THE HAN: POLICY DECISIONS THAT TRANSFORMED SOUTH KOREA INTO AN EXPORT POWERHOUSE
}

\author{
Douglas A. Irwin \\ Working Paper 29299 \\ http://www.nber.org/papers/w29299
NATIONAL BUREAU OF ECONOMIC RESEARCH
1050 Massachusetts Avenue
Cambridge, MA 02138
September 2021

I am particularly indebted to David Cole for his advice and encouragement. I am grateful to Carter Eckhert, Anne Krueger, James Lee, Wonhyuk Lim, Marcus Noland, Dwight Perkins, and Il SaKong for helpful comments and discussions. I thank Steven Lee for providing me with a copy of the Dillon Letter. I thank Dartmouth student Kyoung Tae Kim for excellent research assistance. The views expressed herein are those of the author and do not necessarily reflect the views of the National Bureau of Economic Research.

NBER working papers are circulated for discussion and comment purposes. They have not been peer-reviewed or been subject to the review by the NBER Board of Directors that accompanies official NBER publications.

(C) 2021 by Douglas A. Irwin. All rights reserved. Short sections of text, not to exceed two paragraphs, may be quoted without explicit permission provided that full credit, including ()$^{\circ}$ notice, is given to the source. 
From Hermit Kingdom to Miracle on the Han: Policy Decisions that Transformed South Korea into an Export Powerhouse

Douglas A. Irwin

NBER Working Paper No. 29299

September 2021

JEL No. F13,F31,N75

\begin{abstract}
In 1960, South Korea's exports were about 1 percent of GDP, and the country's ability to import depended almost entirely on US aid. After changing its foreign exchange and trade policies in the mid-1960s, Korea saw a surge in exports to more than 10 percent of GDP by the end of the decade. What factors account for the shift in policy that enabled this dramatic export growth to occur? The United States helped initiate the process by withholding financial assistance, pressuring Korea to devalue its currency and reform its foreign exchange regime. Initially, the Korean government resisted taking these steps, but in 1964 it became firmly committed to an export promotion strategy to boost foreign exchange earnings and end its dependence on American aid.
\end{abstract}

Douglas A. Irwin

Department of Economics

Dartmouth College

Hanover, NH 03755

and P̧eterson Institute for International Economics

and also NBER

douglas.irwin@dartmouth.edu 


\section{Introduction}

In the early 1960s, South Korea was close to being considered a failed state. It suffered from political turmoil and economic stagnation. One of the poorest countries in the world, it had a lower per capita income than North Korea, and its standard of living was not much higher in 1959 than it had been in 1945. Domestic savings were virtually nonexistent, and foreign assistance was required to finance most domestic investment. Exports were less than 1 percent of GDP, and it could afford imports of about 10 percent of GDP only because of US foreign aid.

Today, South Korea is an economic success story and an export powerhouse. The key transition period is widely agreed to have been the mid-1960s, when it began a sustained period of rapid economic growth. Although the many factors behind the country's transformation are still debated, the decision to promote exports is generally accepted to have been a key part of its success. In 1959, South Korean exports were just 0.7 percent of GDP. A decade later exports were about 10 percent of GDP, and by the early 1970s they reached 20 percent of GDP.

The contribution of exports to South Korea’s economic performance has long been studied. ${ }^{1}$ Less well known are the reasons why policymakers decided to undertake a policy of export promotion that contributed to the country's remarkable transformation. Who were those policymakers, and what were the motivations for the policy changes they introduced?

This paper examines the policy decisions and policymaking context of Korea's shift to export promotion in the mid-1960s. Credit is often given to President Park Chung-hee, who seized power in 1961 and presided over Korea's high growth period, for demanding that exports

\footnotetext{
${ }^{1}$ See Frank, Kim, and Westphal (1975); Hong (1979); Krueger (1979); Jones and SaKong (1980); Westphal and Kim (1982); Haggard (1990); and Kim (1991b), among many other works. Connally and Yi (2015) suggest that Korea's trade reforms between 1962 and 1989 can explain 17 percent of South Korea's catch-up to the G7 countries in value-added per worker in the manufacturing sector and that the reforms contributed to investment and productivity gains through the adoption of better technology.
} 
increase. However, in his first three years in power, Park did not adopt export-oriented policies, aiming instead to promote capital-intensive manufacturing through state-led industrial policies. He also pursued expansionary macroeconomic policies and refused to devalue an increasingly overvalued currency, which led his government to impose stringent import controls to stop a precipitous decline in foreign exchange reserves.

The United States opposed the military government's initial policy stance and withheld aid to force it to devalue the won and liberalize the foreign exchange regime. With US encouragement, the previous, short-lived administration of Chang Myŏn had introduced these liberalizing reforms to stimulate exports and reduce the rent-seeking that came with government allocation of foreign exchange. Although these changes were deeply unpopular in Korea and resisted by government officials, the United States wanted a return to those policies and had enormous leverage because it financed most of the country's desperately needed imports. In 1964, the Park government, in a weakened position because of domestic crop failures, relented and appointed an economic reform team that was strongly committed to export promotion as a national priority. Expanding exports was seen as a way of earning foreign exchange to pay for imports and ending the country's excessive dependence on the United States.

This paper seeks to shed light on the political economy of trade policy reform by examining why and under what circumstances such reforms took place in South Korea. It is close in spirit to the work of Haggard, Kim, and Moon (1991), who look at the domestic political economy of Korea's move toward export promotion. This paper focuses more on the policies and policymakers themselves and highlights the role played by the United States, which consistently pushed successive Korean governments to adopt a realistic exchange rate and reform the 
country’s foreign exchange system. ${ }^{2}$ The Korean authorities were reluctant to undertake these unpopular measures until President Park became fully committed to an export promotion strategy in 1964-65. Neither South Korea nor the United States wanted the country to remain so dependent on American aid; both wanted it to be more self-reliant. South Korea appears to be a case in which external pressure and encouragement helped activate the movement toward reform.

This paper is organized as follows. Section 2 provides an overview of Korea's foreign exchange policies in the 1950s, which included the deliberate overvaluation of its currency to maximize American aid along with foreign exchange rationing. Section 3 examines the tentative reforms under the short-lived democratic government of Chang Myŏn in 1960-61, which presaged many of the later changes, particularly a significant devaluation to reduce the political graft associated with the rents from import restrictions and a unified exchange rate. Section 4 covers the first three years of Park Chung-hee's military government, which resisted American advice and was forced to tighten import controls and return to multiple exchange rates in the face of mounting balance of payments difficulties. Section 5 turns to the 1964-65 policy changes, which included a large devaluation, adoption of a unified and flexible exchange rate, the relaxation of foreign exchange controls, and numerous export promotion policies, most of which had been urged by US advisers. Implementation of these policy changes was led by Chang Kiyoung, Korea’s leading economic policymaker, who directed a reform team that was deeply committed to increasing exports. Section 6 discusses why the reform period came to an end in

\footnotetext{
2 This paper draws on earlier studies by USAID officials who worked in Korea in the mid-1960s, including Cole and Lyman (1971), Brown (1973), Mason et al. (1980), Cole (2014), and others. The Korea Development Institute (KDI 2016) complied an oral history of many of the Korean policymakers involved in government at this time. The reminiscences of Kim (1994, 2011) also provide insights into the reform process.
} 
1967 and examines the role played by industrial policy during this period. Section 7 offers some concluding observations.

\section{Floundering in the 1950s}

Beginning in 1392, Korea banned private foreign trade, allowing only limited, government-controlled trade. Known as the "hermit kingdom,” Korea rebuffed mid-19th century attempts by the West to engage in commerce, choosing instead to remain economically isolated and avoid Western domination. ${ }^{3}$ Although it succeeded in avoiding Western domination, Korea failed to avoid domination by Japan, which forced Korea to open its ports in 1876 and then annexed the country in $1910 .{ }^{4}$ Trade grew to become a significant fraction of Korea's economic activity. In 1940, exports were 31 percent and imports 43 percent of Korea’s GDP (Hong 1979).

Korea regained its independence after World War II but was partitioned in 1945 into an American-backed South and a Communist-backed North. At that time, South Korea was significantly poorer than North Korea, which had most of the peninsula’s industry and natural resources.

The Korean War (1950-53) was a further economic setback to the already destitute South. Wade and Kim $(1978,246)$ describe the state of the country after that conflict:

"In 1953, Korea was an extremely poor country in every sense of the term: it was overpopulated, productivity was low, subsistence living standard prevailed, natural resources were meagre, the economy was primarily agricultural, and illiteracy was still high;

\footnotetext{
${ }^{3}$ Lee and Temin (2010) suggest that Korea chose economic isolation because engagement through trade was thought to threaten the country's political stability.

${ }^{4}$ In lieu of measures of income, Kim and Park (2021) show that biological living standards (such as measures of height) improved as a result of the opening of trade.
} 
moreover, savings and investment were low, foreign trade was nil, a comprehensive development strategy had not been formed, public institutions were arbitrary, inchoate, inexperienced, and both elite and popular morale was demoralized and often cynical. Few countries in the world offered fewer ostensible prospects for broad, rapid and prolonged economic development.”

South Korea limped through the 1950s with lackluster economic growth (of about 4-5 percent), high unemployment, large budget deficits, chronic inflation (of about 30 percent a year), and a persistent balance of payments shortfall that was filled by US foreign aid. Between 1953 and 1961, US foreign aid financed about 70 percent of Korea’s imports and 75 percent of its total fixed capital formation (Haggard, Kim, and Moon 1991). For most of the 1950s, exports amounted to only about 1 percent of GDP; imports were about 10 percent (Nam 1995).

The policies of the government contributed to the lack of developmental progress. President Syngman Rhee, who was elected in 1948 and served until 1960, neglected the country’s economic development. His overriding goal was to unify the country through military conquest—reflected in the slogan "march north for unification"—-something the United States strongly opposed. ${ }^{5}$ Rhee sought to maximize US military and economic assistance to keep the economy going until the day of reunification arrived. To ensure the continued flow of American aid, he had a perverse incentive to keep the economy weak. ${ }^{6}$

\footnotetext{
${ }^{5}$ The Rhee government had "an unwillingness to build up the South as an independent and integrated economy. The possibility of unification would again give access to the electric power and heavier industries of the North was given as a reason for holding down the growth of such facilities in the South," Cole and Lyman $(1971,166)$ observe.

${ }^{6}$ The few Korean economists who recommended a different approach were ignored. As Cole and Lyman (1971, 79, 81) note, "The regime as a whole remained resistant to the ideas of those within its ranks who had professional economic expertise, blocking their advance in the bureaucracy and otherwise failing to encourage their work." This resistance "contributed to a general sense of despair and pessimism about the prospects for economic growth in the South, even among advocates of improved policies."
} 
Korean economic policy in the 1950s was built around "the three lows"-low grain prices, low interest rates, and a low price of foreign exchange—and the controls needed to maintain them. Although the controls led to perpetual shortages of grain, capital, and foreign currency, each had a rationale. The government sought low grain prices to keep the cost of living down, relying on grain imports from the United States made available through PL 480 (food assistance) grants. The government maintained interest rate ceilings, ostensibly to help borrowers and promote investment, but negative real interest rates meant there was little incentive to save, diminishing investment and financial development. The government kept the price of foreign exchange artificially low to make imported goods, particularly capital goods, cheaper than they otherwise would have been.

The low price of foreign exchange meant that the Korean currency was significantly overvalued and the excess demand for foreign exchange was substantial. The overvaluation priced Korean goods out of the world market and kept exports at less than 1 percent of Korea's GDP for most of the decade. The overvaluation also made the price of foreign goods very low and fueled a huge demand for imports. Such imports were needed to maintain South Korea's minimal standard of living and keep domestic production going. The dominant source of foreign exchange came from US grants and loans, which allowed Korea to afford imports of about 10 percent of GDP.

The shortage of foreign exchange led the government to introduce import controls to conserve foreign exchange reserves. Import licensing was introduced in 1946 to impede the purchase of nonessential foreign goods. In 1949, the Ministry of Finance began preparing a quarterly foreign exchange budget to determine how export earnings and aid inflows should be allocated in purchasing imports. In 1954, the government briefly introduced competitive bidding 
for foreign exchange. The bidding rate in 1954 was 46-69 won per dollar when the official rate was 18, but the government soon returned to rationing (Yoo 2020).

To guide decisions about foreign exchange allocation, in 1955 the Ministry of Commerce and Industry began categorizing imported goods as automatically approved, a category granted to less than 10 percent of total importable items; restricted, which required government permission; and prohibited, where local production could satisfy domestic demand. The government maintained high tariffs (about $40-45$ percent on average), to capture as revenue some of the rents that accrued to importers, who reaped a large scarcity premium when they received permission to buy foreign goods. ${ }^{7}$ It also maintained a complicated system of multiple exchange rates, which differed according to the sources of export earnings and the uses of the foreign exchange.

These import restrictions were not part of a deliberate plan to promote infant industries or pursue an import substitution strategy for development purposes. Rather, the restrictions emerged from an ad hoc effort to manage the balance of payments. ${ }^{8}$

Of course, a devaluation to establish a realistic exchange rate might encourage exports and discourage imports, thereby relieving the balance of payments problems. But the Rhee government resisted any devaluation, because it benefited from the overvaluation of the won. Under the "advance agreement” reached just after the outbreak of the Korean War in 1950,

\footnotetext{
${ }^{7}$ As Kim (1991b, 36) notes, "Because the domestic currency was almost always overvalued in the face of rapid domestic inflation, tariffs were not really effective in discouraging imports during this period even though their rates were reasonably high. For this reason, the government relied mainly on the system of semiannual trade programs to control imports quantitatively. However, a complicated system of multiple exchange rates was used to offset some of the disincentive effects on exports of the won overvaluation."

8 "There was little conscious effort on the part of the government to formulate economic policies from a strategic perspective," according to Lim $(2004,9)$. "Import substitution in Korea was more a result of crony capitalism than a strategy for economic development." The government was also not trying to use selective policy to promote infant industries. As Hong $(1979,96)$ notes, "In the actual execution of import controls, this concept of infant industries seems to have been used in the vaguest possible way in Korea. Instead of selecting an infant industry and protecting it, any protected industry seems to have been regarded as an infant industry.”
} 
Korea would advance won to the United Nations Command for its expenditures in Korea and be reimbursed by the United States in dollars. The Korean government had a strong financial incentive in keeping the domestic currency price of the dollar as low as possible, to maximize the dollars received from a given won advance (Yoo 2017). For example, a disbursement of 100,000 won to support American military operations in Korea would yield $\$ 10,000$ if the exchange rate was 10 won to the dollar but only $\$ 5,000$ if the exchange rate was 20 won to the dollar. ${ }^{9}$

The Rhee government also benefited from the overvalued currency because import controls helped build domestic political support for the regime. Those granted access to foreign exchange earned scarcity rents by importing goods at artificially low prices and then selling them at a high scarcity premium at home. The government's control over foreign exchange allowed the Rhee government to distribute favors to businessmen and other favored constituencies that would provide kickbacks to the Liberal Party. ${ }^{10}$

However, the artificially low Korean exchange rate meant that the United States was paying more dollars than necessary for every won spent for local expenses. At a time when Congress was seeking to reduce the foreign aid budget, US economic advisers repeatedly pressed the Korean authorities to devalue their currency. The goal was not simply to economize on American foreign aid expenditures but to stimulate Korea’s export earnings, so that it would be less dependent on foreign assistance in paying for imports. The overvalued currency had a devastating effect on the country’s merchandise exports, which declined from $\$ 40$ million in

\footnotetext{
${ }^{9}$ As Yoo $(2020,4)$ notes, "The agreement determined the direction of the exchange rate policy from the rest of the decade. Throughout the 1950s, despite rampant inflation, the official exchange rate was kept low and devaluation was delayed as long as possible, obviously to maximize the dollar receipt for a given amount of won advance. The lower the won-dollar exchange rate, the greater the amount of dollars received."

${ }^{10}$ See Lim (2004). Haggard, Kim, and Moon 1991, 855) argue that "the government was poorly insulated from the demands of the private sector and was penetrated by patron-client networks. The economic bureaucracy was subject to political interference from both the executive and the ruling party.”
} 
1953 to just \$16 million in 1958, a year in which imports were $\$ 370$ million. Korea did little to promote exporters aside from a variety of haphazard measures, such as partial and selective export subsidies to compensate for the overvaluation and tariff exemptions on some raw material and intermediate goods imports. ${ }^{11}$

To the frustration of US officials, the Rhee government ignored repeated calls for a devaluation. ${ }^{12}$ In 1957, for example, the official exchange rate was 50 won per dollar when the equilibrium rate was thought to be 80-100 won. Rhee issued a directive that "all necessary economic adjustment" be made to keep the exchange rate at its current level. The "defense of the overvalued exchange rate seemed almost a matter of life and death for the Rhee government,” Woo $(1991,64)$ observes. The government argued that increasing the price of foreign exchange (a devaluation) would raise the cost of imported goods and thereby fuel inflation. The unstated Korean concern was that a more realistic exchange rate would reduce the aid dollars flowing in from United States.

In 1957, Congress decided to reduce spending on US foreign assistance and shift from military aid in the form of grants to economic assistance in the form of loans. US aid to Korea was pared back from \$383 million in 1957 to \$222 million in 1959 (Brazinsky 2007). American officials were particularly concerned about the reluctance of the corrupt Rhee government to take

\footnotetext{
${ }^{11}$ A more significant change was the introduction of an export retention scheme in which exporters had the right to retain foreign exchange earnings at the official exchange rate. Another tentative step in the direction of liberalization was the 1959 tariff exemption on imports of some raw materials and intermediate goods to help exporters.

12 The top US economic adviser in Korea from 1956 until 1960, Edwin Cronk (1998, 7), recalled, “The exchange rate was way, way off a realistic limit. . . such that there was no money to be made in exporting anything, because with the official exchange rate you wouldn't end up with enough to pay for your raw materials or your labor. But millions could be made by importing anything; anything that was usable-say rice, or cement, or any of the basics. If you were one of the lucky ones to get an import permit, which was of course issued by the government, you were an instant millionaire! It was this distortion of the exchange rate which was one of the central problems, and we couldn't do anything about it. Now, I felt then —and I feel even more strongly now — that if we had just laid the law down, and said, 'You either [adjust] the exchange rate, or we're going to cut the AID program back to the very bone, and let you take the consequences.' We could have been tougher, much tougher”
} 
steps to improve its stagnant economy. South Korea was the largest recipient of US foreign aid and was often disparaged as a corrupt sinkhole. ${ }^{13}$ Officials worried that South Korea would never become a self-sustaining economy and would always be dependent on the United States. For US officials worried about Cold War competition, the fact that North Korea's economy appeared to be in better shape than South Korea's was a particularly alarming development. ${ }^{14}$

American advisers began to increase pressure on the Rhee government for policy changes, not just to stop the endemic corruption but to increase exports and close the enormous gap with imports. Despite US pressure, Korea kept delaying consultations on the matter. In January 1960, the US Embassy in Seoul unilaterally changed the exchange rate at which it would reimburse expenses to 65 won per dollar. The government reluctantly made the exchange rate change official the following month.

The aid reduction and devaluation threatened Rhee’s domestic political position. He responded not by embracing economic reforms but by engaging in political repression.

\section{Tentative Reforms under the Chang Myŏn Government}

Mass student protests against political repression and the blatant rigging of the March 1960 national elections forced Syngman Rhee to step down. In July 1960, an election brought the Democratic Party, headed by Prime Minister Chang Myŏn, to power.

\footnotetext{
${ }^{13}$ A US Comptroller General (1962) report expressed concern about widespread corruption in Korea related to the foreign exchange allocation. See Krueger and Ruttan (1989) for an evaluation of US aid to Korea.

${ }^{14}$ As Kim and Baik $(2011,60)$ state, “The North Korean threat . . . was psychological and political, making the South look like a hopeless case of poverty, social anomie, and political instability that was destined to lose the interKorea competition to become the sole legitimate government of the entire Korean peoples. In 1961, North Korean per capita GNP stood at \$160, twice that of the South, and the gap in economic performance was rising.” On relations with the US during this period, see Lee (2006).
} 
The Chang government was committed to a more open and liberal political and economic system. Rather than hold out hope for Korean reunification, it vowed to focus on economic development and root out political corruption. The objectives were closely related: The Democratic Party had long called the low exchange rate a "disguised subsidy" for cronies who were close to the government (Yoo 2017, 17). The new finance minister was in favor of liberal market reforms as a way of ending corruption stemming from the nontransparent allocation of foreign exchange and government loans.

The United States was relieved that Rhee was no longer in power and pledged to support the new government in its reform effort. ${ }^{15}$ Under-Secretary of State Douglas Dillon offered \$35 million in assistance if the government agreed to raise the exchange rate (devalue) and increase transport and electricity rates (to reduce costly government subsidies and shrink the budget deficit), among other conditions. Of that sum, \$20 million was earmarked to deal with the fallout from a devaluation, \$10 million was set aside for the purchase US agricultural products to keep food prices from rising, and $\$ 5$ million was additional defense support. ${ }^{16}$

The "Dillon Package" was set out in an October 25, 1960 letter from Dillon to Chang, with the requirement that the reforms be implemented by March 1, 1961. Although officials worried about the political fallout from these policies, the Chang government desperately wanted

\footnotetext{
${ }^{15}$ As an August 20, 1960 telegram from the State Department to the US Embassy in Seoul stated, "We have been pleased to note that the Democratic Party recognizes the need for basic exchange reform. US has long believed that establishment of a realistic unitary rate system is essential to sound development and stability of Korean economy. US govt attaches so much importance to this that we expect discuss subject in detail with ROKG [Republic of Korea Government] in near future” (US State Department 1994, 688).

${ }^{16}$ National Security Council document 1068, dated November 1960, stated that a primary US goal was to ensure that Korea would become a self-supporting economy. To do so, the United States should press for "reforming the foreign exchange system so as to reduce the tendency to import and stimulate domestic production for both export and domestic use; normalizing commercial relations with Japan; eliminating excessive bureaucratic controls; reforming the tax structure, improving business practices and rationalizing utility rates” (US Department of State 1994, 702).
} 
American backing and agreed to the proposal, working quickly to meet the deadline. ${ }^{17}$ The government devalued the won in two steps. In January 1961 it devalued from 65 won to 100 won per dollar. A month later, it devalued to 130 won per dollar. The February 1961 devaluation was made in conjunction with a major reform of the foreign exchange system. ${ }^{18}$ The government rationalized the complicated multiple exchange rate system and began to relax import controls, paving the way for a fully unified exchange rate in June of that year.

The devaluations of 1960 and 1961 significantly reduced the overvaluation of the won. The black-market premium dropped from near 180 percent to about 30 percent (figure 1), increasing the profitability of exporting. The payoff came quickly, with exports jumping from \$19.8 million in 1959 to \$32.8 million in 1960 and \$40.9 million in 1961, finally surpassing their 1953 dollar value. ${ }^{19}$ More importantly, nontraditional labor-intensive manufactured exports started to grow rapidly starting in 1963 (Yoo 2017).

The Chang government devalued mainly as part of its anti-corruption campaign, as it sought to eliminate the rents associated with the currency's overvaluation and the government's allocation of foreign exchange. There was some hope that the devaluation would stimulate exports but no inkling that it could fundamentally transform the economy into an export-led growth model. ${ }^{20}$

\footnotetext{
17 "Having witnessed the influence of the threat of withdrawal of US aid on the collapse of the Rhee government, the new government's first concern was to secure American backing by being highly solicitous of American interests and advice," $\operatorname{Kim}(1975,212)$ notes.

${ }^{18}$ On the politics behind the devaluation, see Ryu (2017).

${ }^{19}$ The main driver of exports was the devaluation, as the exchange rate went from 65 percent of its realistic value to 98 percent in 1961, according to Brown $(1973)$. Yoo $(2017,14)$ suggests that the foreign exchange reform of early 1961 was the initial trigger for the rapid expansion of exports that continued over the next decade: "It is highly likely that the reform made it possible for those who had not been in the export business to see for the first time the profitable export opportunities, which had been hidden behind the veil of complex and distorted foreign exchange system.”

${ }^{20}$ According to Yoo $(2017,17)$, “The Democratic Party for years had labeled the unrealistically low official exchange rate a 'disguised subsidy' to their cronies by those in power. For instance, if a politician, by exercising some influence on the relevant ministry, had a certain amount of government-held dollars be allocated to his
} 
Figure 1

Black market premium on the Korean won, 1956-70

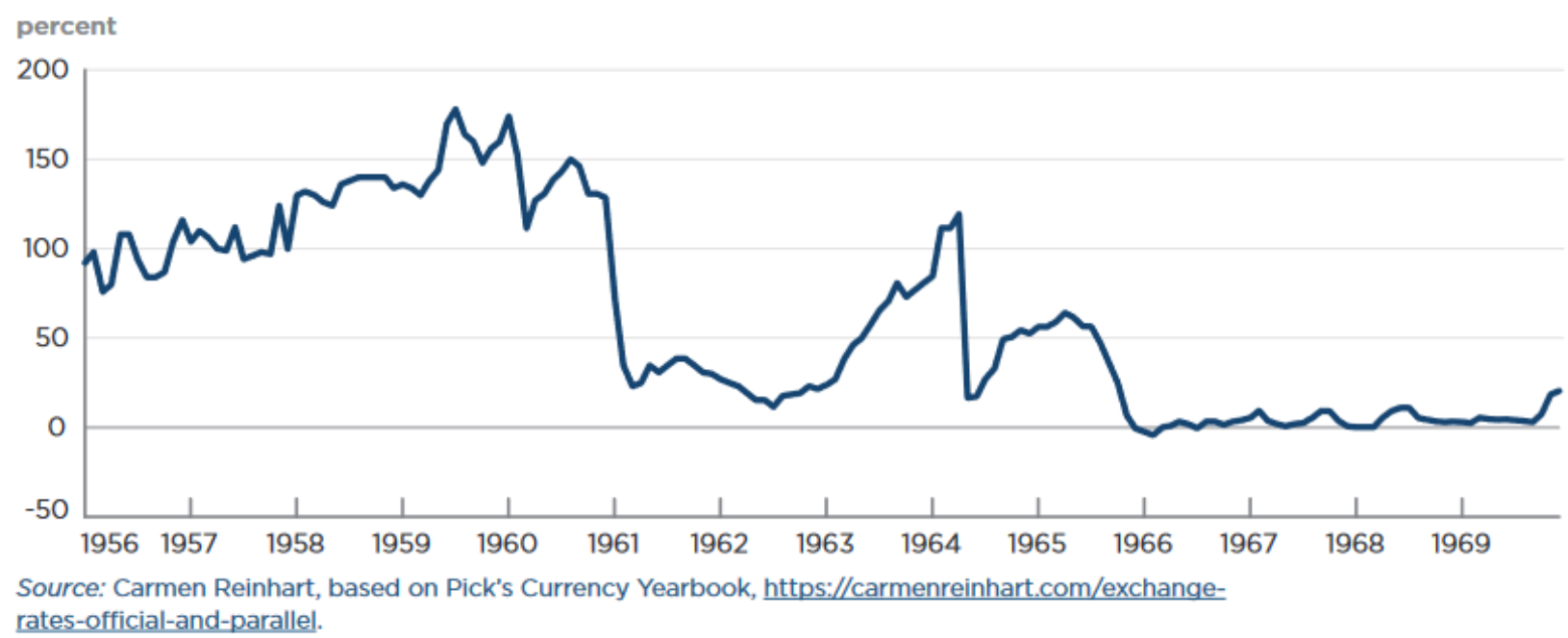

However, the immediate impact of the Dillon package was short-term pain. In the first two months of 1961, prices rose 15 percent, and industrial production, which depended on cheap imported intermediate goods, fell. ${ }^{21}$ The devaluation hurt the political fortunes of the deeply divided government, which went through several major cabinet reshuffles during its short period in power and never enjoyed strong public support. The government was widely seen as inept, and public dissatisfaction with the country's situation led to protests. ${ }^{22}$

political supporter(s) at the official exchange rate, far below the on-going market rate, it certainly would be an egregious example of corruption. The Democratic Party had promised to eradicate this source of wide-spread corruption, if it seized the power. Apparently, it was not even dreamed that the reform would start the rapid export expansion that eventually led to the great economic transformation called 'East Asian Miracle.' Daily newspapers of those days carried no report to the effect that Democratic Party anticipated or promised an increase in exports, creation of new jobs, progress in industrialization, and so on as the economic effects of the reform. It seems certain that the reform of foreign exchange system was meant to be, more than anything else, an anti-corruption measure.”

${ }^{21}$ According to $\operatorname{Kim}(1975,212)$, "The results were disastrous. When the exchange rate changed, the cost of imports on which the economy depended doubled, producing panic and spiraling inflation."

${ }^{22}$ As one former official put it, "We had simply let the people shout for political reforms and further democratization: We didn't have the time to address domestic political demands while the entire cabinet was focused so heavily on implementing the Dillon memo" (Satterwhite 1994, 329). 


\section{The Initial Stance of the the Park Regime}

After renewed political unrest and street demonstrations by students, a military coup overthrew the nine-month-old Chang Myŏn government on May 16, 1961. The military authorities under General Park Chung-hee declared martial law and pledged to oppose communism, eliminate corruption, seek unification, and build a self-sufficient economy. ${ }^{23}$

The military leaders believed the state should bring discipline, stability, and order to the country. They believed economic development was an essential priority and brought energy and a sense of urgency to the task. At the same time, the military leaders "had only the vaguest notions of economics and politics," according to Samuel Berger, the US ambassador to Korea at the time $(1966,4) .^{24}$

The military government pushed forward with two unfinished initiatives from the previous administration. In June 1961, it established the Economic Planning Board, an economic super-ministry designed to streamline economic policymaking and bypass the old corrupt bureaucracies. A month later, it released the First Five-Year Economic Plan, which updated the targets and goals for the Korean economy developed by the previous administration. ${ }^{25}$ The new plan did not emphasize export expansion but “called for constructing a self-reliant economy

\footnotetext{
${ }^{23}$ See Kim (1975, 227). Among the many detailed assessments of Park's government and its economic policies are Kim (2004), Kim and Vogel (2011), Kim and Sorenson (2011), and Cho (2019).

24 "The junta's leaders were bold, nationalistic, and determined to improve conditions in their country," Brazinsky $(2007,128)$ writes. "But at the same time they were truculent, autocratic, and mistrustful of American advice." ${ }^{25}$ The EPB played a coordinating role above the various ministries that were responsible for executing policy. According to Kim (2011, 213-14), "It is important to emphasize that the significance of economic planning lay less in offering a technical master plan of industrial growth, with intricate modeling of targets and instruments, than in establishing institutional channels of communication and cooperation and institutional procedures for systematic agenda formation, resource mobilization, and policy feedback among the EPB, the MoF, the sectoral ministries, and the auxiliary ministries on an ongoing basis." Cole and Lyman $(1971,218)$ suggest that "the real significance of economic planning was not technical but political, authorizing the EPB to intervene in other ministries' affairs and inculcate society with Park's brassy 'can do' spirit and his daring 'grow-at-all-costs” strategy.” Even as late as 1964, "planning as such was definitely not a well-established or influential process in the Korean government.” It soon became important.
} 
through inward-looking import-substitution industrialization” (Kim and Baik 2011, 75). The government envisioned state investment to build up heavy and chemical industries to increase national security and end the country's dependence on US aid and foreign sources of supply. Given Korea's enormous trade deficit and tiny export base, the government thought it easier to replace imports by expanding domestic production of those goods rather than to try to make up the gap by exporting more. The plan was to make the country self-reliant in its ability to pay for its imports, but the plans were formulated "without due consideration of South Korea’s short supply of capital and technology,” as Kim and Baik $(2011,75)$ note. ${ }^{26}$

The plan ran into stiff US opposition. American advisers worried that large-scale investment in capital-intensive production was the wrong strategy for a poor, low-saving country that had an abundance of unskilled labor and a severe shortage of capital. US advisers had long argued that Korea should focus on increasing productivity in agriculture and promoting laborintensive export industries. Although they did not envision an export-led growth model for Korea, they did not think that import substitution was appropriate, given the country's circumstances. ${ }^{27}$

Korea's military leaders did not just ignore the American advice; they did not want even to hear it. The US-Korean Economic Coordination Commission failed to meet from 1961 to 1963. President Park was just as stubborn as Rhee had been when it came to accepting economic

\footnotetext{
${ }^{26}$ As Kimiya (2011, 67) writes, "The military junta initially adopted an autarkic industrialization strategy known in Korean as 'inward-looking industrialization." According to the memoirs of the people who played an important role in drafting the original five-year economic plan, "they had the clear intention to construct a self-reliant national economy by investing huge sums of capital in basic industries." The export projects were wildly optimistic, and "it is doubtful that the planners had much of an idea as to how the targets might be achieved," Cole and Lyman (1971, 211) observe. "While the original plan mentions the desirability of and some policy measures for export expansion, it explicitly states that the policy's priority was import substitution," notes Yoo (2020, 23). "Simply, the government did not consider export promotion as a development strategy in 1961" (Yoo 2017, 15).

27 "Rather than directly dictate an export-oriented industrialization strategy, the United States only voiced its opposition to the inward-looking deepening strategy,” Kimiya $(2011,69)$ notes.
} 
guidance from the United States. "They were strongly nationalistic and resentful of their dependence on the United States,” Ambassador Berger $(1966,5)$ recalled. “They recognized that Korea must tolerate the Americans, but they resented our advice as interference.”28

The United States stood in the way of the military's attempt to pursue an industrialization strategy based on heavy industry. ${ }^{29}$ Korea abandoned a plan to construct an integrated steel mill after the United States refused to provide financing and blocked a potential loan from West Germany. The military government tried to bypass the United States and raid the supposed "idle cash” in Korean banks by freezing all accounts in June 1962. The theory was that massive unused funds in the banking system could be directed to state-supported investment projects. US advisers in Korea had not been given advanced warning of the plan, thought it was a terrible idea, and immediately stopped the disbursement of aid until the government unfroze the bank accounts, which it soon did.

The military government also considered initiating the local assembly of automobiles, television sets, and watches through the use of imported components and assembly kits. These plans were shelved, because they would have required large amounts of foreign exchange. Not only would the final products have been of insufficient quality to be exported and earn foreign exchange, but the imported components would have been expensive and cost foreign exchange. As a result, the projects would have been a net drain on the country's scarce reserves. ${ }^{30}$

\footnotetext{
${ }^{28}$ A June 1961 presidential task force on Korea noted that "the new regime will be tough, determined and difficult to deal with. Its authoritarian and nationalistic stamp suggests that it will not be readily receptive to US guidance and will seek to a search South Korea's independence in military, economic and political affairs" (Presidential Task Force on Korea 1961, 35-36). See Park (1999) and Brazinsky $(2005,2007)$ for the changes in US foreign policy with respect to Korea during the early 1960s.

29 "Among the various factors that led to the failure of inward-looking development, the most important was the US government's opposition,” notes Kimiya (2011, 71).

${ }^{30}$ As Luedde-Neurath $(1986,55,86)$ note, "What all these projects had in common was that they were prestigious, foreign exchange intensive, and likely to neither save nor earn significant amounts of foreign exchange, while arguably not being urgently necessary.... The purpose of citing the above examples is to show that in its early days at least, the Korean government did start off down the road towards a questionable form of industrialization
} 
The military government departed from the US-backed stabilization program and began to run up deficit spending. As a result, inflation began to pick up, with wholesale price inflation jumping from 6 percent in 1962 to nearly 30 percent in 1963 (Yoo 2020). With the value of the won having been fixed since the 1961 devaluations, the Korean currency once again became overvalued, as indicated by the rising black-market premium (shown in figure 1). The stimulus to domestic demand led imports to soar, from \$316 million in 1961 to \$560 million in 1963 (Yoo 2020). With US aid being curtailed, the growing gap between export receipts and import payments was financed through the steady depletion of foreign exchange reserves, which fell from \$214 million in March 1962 to $\$ 107$ million by September 1963.

A food crisis exacerbated the situation. A barley crop failure in the spring of 1963 compounded the effects of the poor rice crop in 1962, putting the country on the brink of famine. The country lacked the resources to buy sufficient food from the rest of the world, increasing its dependence on the United States.

Despite the growing balance of payments problems, the government ruled out any devaluation; the public unrest after the 1961 devaluation was still a recent memory. To conserve foreign exchange, the government turned to various export promotion schemes to boost export earnings and more stringent import controls to restrain spending on foreign goods. In September 1961, it introduced export subsidies of 3-8 percent, later expanding them to compensate exporters for the growing currency overvaluation. ${ }^{31}$ It reduced the tax on export earnings by 30 percent in 1961 and another 50 percent in 1962. In May 1962, it established the Korea Trade

involving inessential projects, excessive commercial credit, questionable technology transfers, and above all a massive foreign exchange burden.” These projects were quickly terminated because of their costs rather than perpetuated despite their costs, as might have happened in other developing countries.

31 "Although it started to promote exports in the face of declining foreign aid, most of the export promotion measures adopted during that period had the characteristic of ad hoc measures to offset the disincentive effect of an overvalued exchange rate on exports,” writes $\operatorname{Kim}(2019,131)$. 
Promotion Agency (KOTRA), to collect and disseminate information on foreign markets in order to help exporters overcome the difficulty of entering foreign markets.

As the balance of payments situation worsened in 1963, the military government started clamping down on imports. The government reintroduced multiple exchange rates through an export-import linking mechanism in which exporters would earn nontransferable rights to use a portion of their foreign exchange earnings to buy imports. This mechanism was a way of automatically tying imports to exports and thus eliminating the need for the government to allocate foreign exchange among importers. It was also an indirect subsidy to exports, because the imports could be sold in the domestic market at a premium. ${ }^{32}$ However, by the second half of 1963, exporters were allowed to keep only 20-25 percent of their foreign currency earnings; they had to turn over the remainder to the government at the official exchange rate. In the first half of 1963, the government slashed the number of automatically approved imports. In the second half of the year, it suspended the automatic approval system altogether, so that all imports needed official permission. In November, it required a 100 percent advance deposit on goods imported on credit.

As Korea’s economic difficulties mounted, relations with the United States deteriorated. US advisers were dismayed by the economic policy choices being made by the military government. Even before the problems of 1963 emerged, the United States was frustrated by the

\footnotetext{
32 As Cole and Lyman $(1971,189)$ note, “The linking rights in addition gave exporters special access to import licenses for the most restricted, and therefore the highest profit, imported goods. These two types of subsidies made possible continued rapid growth of exports in 1963 and 1964, despite the increasingly overvaluation of the exchange rate and the high levels of domestic demand associated with the inflation.”
} 
lack of progress Korea had been making in improving its economy, in particular its inability to become self-reliant. ${ }^{33}$

The Kennedy administration came into office prepared to take a tougher line with Korea, including scaling back aid (Park 1999). The US Operations Mission (USOM) in Korea reduced economic development grants to Korea from \$178 million in 1961 to \$92.5 million in 1962 (Brazinsky 2007). ${ }^{34}$ Furthermore, a June 1961 presidential ) task force noted that "experience has shown the effectiveness of sanctions based upon withholding of increments of economic aid as a means of ensuring Korean performance. Accordingly, US influence should be reinforced by making economic development assistance (as distinguished from supporting assistance) available in increments which can be withheld in the of Korean failure to carry out agreed programs” (Presidential Task Force on Korea 1961, 35-36). ${ }^{35}$

At the US Embassy in Seoul, Ambassador Samuel Berger and USOM director James Killen, a tough labor negotiator, were prepared to implement the proposed strategy of withhold aid. Korea’s precarious economic situation in 1963 put the United States in a particularly strong position to influence Korean policy. Berger and Killen began to use aid as leverage to force the military authorities to take two steps they did not want to take: (a) hold democratic elections and return to civilian government and (b) adopt policies to stabilize the economy and lay the foundation for growth so that Korea could become self-sustaining.

\footnotetext{
33 “Throughout the tenure of Killen and Berger, US pressure for stabilization remained high, which provoked strong resentment from South Korean officials,” according to Kim (2011, 77). For American attempts to educate Park on economic policy, see Brazinsky (2005).

34 The USOM oversaw US Agency for International Development (USAID) operations in Korea.

${ }^{35}$ A US Comptroller General $(1962,11)$ report agreed that "the present state of Korean political and economic sophistication and the history of the aid program over the past years do not offer any reasonable basis for believing that the formidable task of carrying through the hard internal measures vital to Korean economic development . . . is within the capability of the Korean Government without cooperative guidance, forceful support, and effective surveillance by the United States.”
} 
The first objective was political. The United States did not support the 1961 coup and had long pressed the military to step aside and hold elections to transition to a civilian government. In March 1963, General Park surprised and dismayed the United States by announcing not an election date but a referendum to determine whether the military should stay in power. Berger immediately suspended aid. A few weeks later, the announcement was rescinded, the election was scheduled, and the aid was released.

To get the stabilization program back on track, Killen also withheld economic aid from Korea, including PL480 food assistance at a time when food was in desperately short supply. In April 1963, Korea agreed to a new stabilization program to reduce the budget deficit, in the hope of bringing inflation under control. The government also agreed to dismantle trade controls and eventually adopt a floating exchange rate. Aid was released, but by July it was clear the government was not living up to the agreement. Therefore, Killen requested and received authorization to stop the scheduled disbursement of \$15 million stabilization assistance and to suspend approval of new development assistance if an August review was not satisfactory.

The International Monetary Fund (IMF) echoed US concerns about the direction of Korea's economic policy. In October 1963, after an August staff mission to Seoul, it suggested that the complex export subsidy and import control measures were not a long-term solution to the balance of payments problems, hinting instead that an exchange rate adjustment was needed. “A more lasting solution to Korea's payments problem lies not in these piecemeal incentive measures, but in the attainment of internal financial stability through sound monetary and fiscal policies, including the establishment of a unified [exchange] rate at a realistic level,” IMF (1963, 
14) staff concluded. ${ }^{36}$ Korean officials conceded that the exchange rate was too low for exporters but said there were no plans to devalue the won because, they argued, doing so would simply fuel inflation.

Park was narrowly elected president in October 1963. He campaigned on a "Korea first" policy that recognized that as long as it was dependent on American aid, the country was not fully sovereign. In a campaign book, The Country, the Revolution and I, Park (1963) set out his vision for Korea to become a modernized, industrialized nation. Korea was only "nominally" independent, he wrote, because half of the government's budget came from the United States. ${ }^{37}$ As he put it (Park 1963, 21):

"Just imagine one person depending on another for half, or more, of his living expenses for ten years or twenty years; having no other reason for so doing than that the other person once helped him or is still helping him or that he has no ability to help himself. . . . For twenty years we have kept our house in this manner! One full generation has passed! Are we to sit down and spend our livelong days like this forever? Are we to stand by and watch, without any resolution or courage, this process with indifference? What would we do if US aid were cut off tomorrow?”

\footnotetext{
${ }^{36}$ The IMF $(1963,16)$ concluded in a diplomatic way, "While appreciating the constructive efforts made by the Korean authorities, particularly as regards stabilization, the staff team noted that in order to serve the economy well, the exchange rate should be fulfilling more adequately the purposes of promoting exports and restraining imports. . . . The staff team observed further that the present restrictive system appeared to be too complex and tended to cause various economic distortions. ... As more significant expansionary pressures have been generated, the resulting price movements have tended to make the [exchange] rate less representative of the true price relationships between the country concerned and the rest of the world. In this sort of situation and in the absence of a large cushion of international reserves, it is difficult to maintain an exchange rate solely by tightening restrictions [on imports] and by using special devices [to support exports].”

${ }^{37}$ Park $(1963,21-22)$ wrote, "Though nominally independent, the real worth of the Republic of Korea, from a statistical point of view, was only 48 percent .... . In other words, the US had a 52 percent majority vote with regard to Korea, and we were dependent to that extent." $\operatorname{Kim}(2004,98)$ notes, "In campaigning for Korea’s autonomy, free from US intervention linked to foreign aid, Park set about systematically eliminating US influence on Korean Government affairs.”
} 
Park $(1963,22)$ confessed that “our government would have to instantly close down if US aid were withheld or withdrawn.” Something had to be done to "preserve our self-respect as a sovereign nation.” Park $(1963,35)$ believed that the construction of “an independent economy and to achieve economic self-sufficiency” was "a task that must be accomplished, at all costs.” By self-sufficiency, he did not mean autarky but simply that the country could pay for the imports it needed with export earnings rather than US aid.

\section{The 1964-65 Policy Changes}

In January 1964, a new civilian government under President Park took over, with the hope of addressing the country’s seemingly intractable problems: rising inflation, a dire food shortage, and falling foreign exchange reserves, all of which reinforced the country's dependence on American assistance.

Having ensured the return to a civilian government, US officials were now ready to push Korea into making what it saw as long-overdue changes in economic policy. A January 21, 1964 telegram from the US Embassy in Seoul to the State Department stated, "We are forcing or trying persuade ROK [Republic of Korea] Govt to make number of difficult decisions during first half this year: A tough economic stabilization program alongside reduced US aid; a ROKJapan settlement; and devaluation.”38

In February, the government revised the First Five-Year Plan and noted the importance of increasing manufactured exports. A few years earlier, the idea of expanding such exports would

\footnotetext{
${ }^{38}$ See https://history.state.gov/historicaldocuments/frus1964-68v29p1/d1. On February 13, 1964, the embassy reported, "In the economic sphere, the primary goal for 1964 should be the pursuit of sound monetary and fiscal policies and the stabilization of price levels. The exchange rate will have to be adjusted to a realistic level some time not later than mid-summer 1964.”
} 
have seemed farfetched, but it now seemed feasible, in light of their rapid growth after the devaluations of 1960-61. ${ }^{39}$ The attention paid to exports reflected recognition not just of their contribution to the economy but of their political importance as well. Because Korea's ability to import still depended on US aid, the United States had been able to use its economic leverage to force the military government to step down in 1963. President Park wanted to ensure that the government would never be in such a position again, which meant increasing exports enough to pay for imports. Korea's exports had been growing rapidly since 1960, but they started from a very small base and still only generated enough foreign exchange to pay for 15-20 percent of the country's imports.

Despite the growing overvaluation of the won since the 1961 devaluation, the Park government still resisted any devaluation, on the grounds that it would exacerbate inflation. But with foreign exchange reserves having fallen to precariously low levels and the United States holding back tens of millions of dollars in potential aid, the Park government could not avoid having to make some adjustments to policy.

In March 1964, President Park, Ambassador Berger, and Director Killen agreed to establish a joint task force to design a new exchange rate system. ${ }^{40}$ Of course, the two sides disagreed on the details. The United States wanted a large devaluation, from 130 won per dollar to something like 285 or even 300 , followed by the adoption of a floating exchange rate. ${ }^{41}$ The Koreans wanted a much smaller devaluation to a new fixed rate.

\footnotetext{
${ }^{39}$ As Yoo $(2017,15)$ notes, "The government did not consider export promotion as a development strategy in 1961. ... This revision of the First Five-Year Economic Development Plan is clear evidence that the policy switched to export promotion was inspired by the rapid export expansion that had begun earlier."

$40 \mathrm{Joo}$ (2017) provides an excellent account of the negotiations and discussions on the Korean exchange rate during this period.

${ }^{41}$ In January 1964, Professor Irving B. Kravis of the University of Pennsylvania completed a report for USAID on economic reforms in Korea, indicating that it should revise its exchange rate to 240 won per dollar to account for
} 
At the end of March, Berger and Killen held up another tranche of economic aid but offered additional support if policies were changed, much like the Dillon letter of 1961. If Korea devalued its currency and adopted a flexible exchange rate, the United States promised $\$ 30$ million in immediate assistance and release 250,000 tons of wheat. At the end of April, Korea agreed to do so. ${ }^{42}$

On May 3, 1964, Korea announced a devaluation from 130 to 255 won per dollar, somewhat less than what American officials had proposed. It also notified the IMF that it was planning on adopting a floating exchange rate. ${ }^{43}$ Secretary of State Dean Rusk praised the devaluation as "an important step toward the strengthening of Korea's foreign exchange earning capability and the establishment of equilibrium in her external accounts.... A new basis now is being laid for investment in industry, expansion of exports, rising employment, and the broad economic and social progress which Korea's energetic and capable people can achieve” (US Department of State 1964, 809). In Korea, however, the devaluation was widely denounced—in the press, in business circles, and in the National Assembly. "A major South Korean newspaper contended that the devaluation would lead to a 'vicious price spiral,'” Brazinsky $(2007,145-6)$

inflation since the 1961 devaluation (MacDonald 1992, Joo 2017). C. Fred Bergsten, then a young staffer at the Department of State, made the exchange rate calculation.

42 This outcome was largely the result of negotiations by James Killen. As Cole $(2014,148-49)$ recalled, "Killen had negotiated a very tough stabilization program with the Korean government. He had forced the Koreans to agree to a large devaluation in May and a very tight money supply target for the end of the year. One of his bargaining chips was to hold up shipments of PL480 food supplies in the face of a severe food shortage following below normal rice and barley crops.”

${ }^{43}$ The Korean statement to the IMF noted, "Although recognizing as the ultimate goal, the establishment of a realistic fixed unitary exchange rate, we believe that Korea’s present circumstances require a flexible rate system for the time being. These circumstances are the need to substantially increase our export and other external earnings in order to maintain the necessary imports for a reasonable level of economic growth and to adjust to a gradually declining volume of foreign assistance” (IMF 1964, 1). 
reports, “while members of the assembly called the decision a 'complete mistake' and contended that it would cause the people great hardship."44

The 1964 devaluation was the first step in what proved to be a decisive shift in Korean economic policy. US pressure also got Korea to open negotiations on normalizing relations with Japan. Even though normalization promised to increase bilateral trade and bring in investment, such a step was deeply unpopular in Korea because of resentment of Japanese colonialism in the past and fear of Japanese domination in the future. When news of the negotiations was made public, massive anti-government demonstrations led to the suspension of the talks and the declaration of martial law.

With protests in the street and his government beset by political factions jockeying for power, Park reshuffled the cabinet. Whether by luck or by design, he brought in reformers who would change the direction of economic policy. On May 9, 1964, less than a week after the devaluation, Park offered the position of deputy prime minister and minister of the economic planning board to Chang Ki-young. The chief executive officer of the newspaper Hankook Ilbo and a former director of research and deputy governor of the Bank of Korea, Chang had just led the delegation that had been negotiating with Japan. Although he lacked any formal training in economics, Chang was a highly effective administrator who was known as "the Bulldozer" for his ability to get things done. ${ }^{45}$

\footnotetext{
${ }^{44}$ As Kim $(1991,107)$ reports, "When the exchange rate reform was announced in 1964, some in the business community, particularly powerful, large business groups, expressed opposition to the reform. Although both export and import-substitute industries could gain by the devaluation, large business groups opposed it because they preferred to operate under extensive controls rather than under a realistic exchange rate and relatively free-market situation.” Some businesses highly dependent on imported raw materials also opposed the devaluation.

${ }^{45}$ For example, in 1963, when food shortages pushed domestic prices up, Chang managed to import 100,000 tons of wheat from Japan and use some of the profits to fund Park’s presidential campaign (KDI 2016). Chang had also worked to turn the Bank of Joseon into the Bank of Korea, the country's central bank, and worked with Professor Arthur Bloomfield from the University of Pennsylvania on the transition.
} 
In offering him the position, President Park asked, "What are the problems of the Korean economy now and how should they be resolved?” Chang replied, “Give me one night to think about it” (KDI 2016, 181). Chang immediately reached out to Kim Chung-yum, an economist and a former vice minister of finance (1962-63) who had worked with him on the March-April mission to Japan. ${ }^{46}$ At one point during the Japan trip, Chang suggested that Kim prepare a report on the future of the Korean economy. Kim wrote a paper arguing that Korea needed to "promote export-led industrialization, like Japan, in order for our economy to survive” (KDI 2016, 430). ${ }^{47}$

After meeting the president, Chang called Kim and asked him the same question that Park had asked. Kim promised to prepare a brief memo and meet him at 6 a.m. the next morning to discuss it. In the memo, Kim repeated his view that Korea needed to stimulate export growth and adopt market liberalization policies to receive IMF support and other foreign loans. ${ }^{48}$ As Kim (KDI 2016, 181) recalled: "the problems with the Korean economy at the time and the proposed solutions were identified quite clearly in the IMF report. ... The IMF's policy recommendations for

\footnotetext{
${ }^{46}$ Kim began his career at the Bank of Korea, where he helped set up the bank's New York office. He received training at the Federal Reserve Bank of New York and later earned a masters' degree in economics from Clark University in Worcester, Massachusetts.

${ }^{47}$ As Kim (2011, 122-23) recalled, "While I was in Tokyo for a month during the negotiations, I met Chang Ki Young nearly every day to talk about the ongoing negotiations. Between our meetings, we talked about Japan's economy, and the future of Korea's economy. During one of our conversations, Chang thought that it would be a good idea if I prepared a report on the future of Korea's economy, which he would cite during a meeting with President Park. In thinking about the report, I reflected on the economies of the US and Japan as models. ... Korea was like Japan, having similar economic characteristics as Japan. It only made sense that Korea's economy should go in the way of Japan's. It was not enough to develop industries through import substitution. Korea had to pursue an export-oriented industrialization policy, focused on development of its own heavy and chemical industries to foster high tech industries.”

${ }^{48}$ As $\operatorname{Kim}(2011,124)$ wrote, "At the time, the IMF was pushing for market liberalization policies that sought to lower trade barriers, liberalize foreign exchange and interest rates, and deregulate trade. But the government pushed back, since it knew the economic impact of such policies would be widely felt, leading to a backlash from business. But I believed market liberalization policies were necessary despite the challenges to improve the industrial base, to promote export-oriented industrialization, to enhance global competitiveness, and ultimately, to drive economic development. So I prepared a report focused on liberalization policies.”
} 
Korea included rationalizing exchange rates and interest rates, trade liberalization, and lowering tariffs. In other words, it recommended an economic restructuring that suited the market. Even though the policy changes were needed, the ministries were too afraid to drive them forward. Because of opposition by businessmen and the media, the Ministers could not carry out any of the IMF's recommendations.”

Chang was referring to the previously discussed IMF staff report from October 1963, which called on Korea to scrap its complex system of import controls and export subsidies and adopt a unified exchange rate.

In essence, Kim believed that the government would have to get rid of "the three lows" the low exchange rate, the low interest rate, and low grain prices—as well as reform the foreign exchange system. The devaluation had already raised the exchange rate; getting rid of low interest rates and low grain prices would be deeply unpopular. Kim warned Chang about the political challenges of implementing such policies: "Raising interest rates will anger firms that borrow a lot, raising the exchange rate will anger importers, and lowering tariffs will anger domestic manufacturers,” Kim warned (KDI 2016, 18). “Eventually, the entire business world will protest the policies. Plus, the National Assemblymen will join them and intelligent media editorialists will criticize the policies ... it will be very difficult.” Chang replied, "Mr. Kim, I will do it. I will be sure to get it done."49

Chang then briefed President Park about the importance of promoting exports and implementing market liberalization policies that were "urgently needed but also were difficult to

\footnotetext{
${ }^{49}$ Chang told him, "I am only willing to join the president's cabinet as deputy prime minister, not as a minister. I am also not willing to join the cabinet unless certain conditions are met. I need to be given full control over economic policy matters, and allowed to pursue my economic policy agenda. If I am given unfettered authority, I am sure that I will successfully implement the market liberalization policies you suggested” (Kim 2011, 125).
} 
implement due to the possible adverse effects of liberalization on protected domestic industries."

Chang also warned the president, "It is imperative that you do not change your mind about the policies after we embark on this process. If you stop the reform because business and industry

protest it, it will be better not to have started at all.” Park is reported to have replied, “Absolutely. I will do as you say to the end” (KDI 2016, 18).

Chang accepted the positions as deputy prime minister and head of the Economic Planning Board (EPB) and dominated economic policymaking over the next three years. ${ }^{50}$ His ability, charisma, and self-confidence won the strong support of President Park and made the EPB the powerful epicenter of economic policymaking. Chang reported directly to the president and controlled all major appointments to the economic agencies, most importantly the Ministry of Commerce and Industry, where export policy and import policy would be developed and implemented. Chang recruited an economic reform team to help introduce sweeping policy changes. Two key members of the team were Park Chong-hoon and Kim Chung-yum, who were appointed minister and deputy minister of commerce and industry, respectively. ${ }^{51}$

\section{Export Promotion}

After the cabinet reshuffle in May 1964, the country’s top economic officials all agreed on the overriding importance of promoting exports. Many of them had experience working in

\footnotetext{
${ }^{50}$ According to Cole and Lyman $(1971,46)$, Chang was "practically given carte blanche in shaping and directing economic policies over the next few years.” Kim (2011) and Rhee (2019) examine some of the bureaucratic and institutional reforms pertaining to economic policy during this period.

${ }^{51}$ After returning to Korea from Japan, Kim Chung-yum became a professor at Yonsei University. He was scheduled to teach courses on foreign exchange and international trade in the spring semester of 1964. "On June 12, while I was busy preparing my lecture for my new teaching post at Yonsei University, I was unexpectedly appointed as the Vice Minister of Commerce and Industry without any prior information or notice,” Kim $(2011,127)$ recalled.
} 
Japan and saw that country's export success as a model to emulate. ${ }^{52}$ Once in office, Park Chong-hoon, who became known as "the export minister," began speaking of an "export first” strategy. In June, he urged President Park to lead the country in an export drive. ${ }^{53}$

The reform team immediately went to work to sustain the growth of exports. In June 1964, the Ministry of Commerce and Industry announced a “Comprehensive Export Promotion Program” to help exporters sell more in foreign markets. Of course, what really helped boost the competitive position of exports was the May 1964 devaluation. The Park government had set the goal of reaching \$100 million in exports in 1964, up from \$87 million in 1963. Within government circles, the target was $\$ 120$ million, which seemed an unrealistic reach. Government clerks worked feverishly with abacuses tabulating the closely monitored incoming data on export sales to see if the target might be met.

On November 30, 1964, South Korea’s exports hit the \$100 million mark. The next day, the commerce minister reported the news to President Park, who shed tears at the achievement. (Ever since, November 30 has been commemorated as "Export Day,” although it was renamed “Trade Day” in 1986 to acknowledge the importance of imports.) A month later, on December

52 "Watching Japan, one of our closest neighbors, achieve remarkable growth through exports, we referred to its export promotion polices a lot. The fact that Japan was right next to us, and became a model of growth from the ashes of war, was helpful to us," noted Hong Sung-jua, a former deputy minister of commerce and industry who was one of the main figures who implemented the export-led strategy (KDI 2016, 432).

${ }^{53}$ He reportedly pleaded with President Park that "exports are the only means to save us. I believe, from now on, we as a nation must strive to implement the export-first policy by designating it as the supreme priority of the nation. And I urge you, Mr. President, that you lead us as the Supreme Commander. I also urge you to encourage us as well to eradicate bottlenecks [to facilitate exports]" $(\operatorname{Kim} 2004,115)$. As $\operatorname{Kim}(2011,130)$ recalled, "When I was appointed the Vice-Minister of Commerce and Industry in early June 1964, export-oriented industrialization polices were needed to compete in the global economy. It was imperative for countries to overcome the limits of small and saturated domestic markets. The implementation of import substitution-based protectionist measures such as an overvalued exchange rate policy, restrictions on foreign trade or foreign exchange, differential duties, and subsidized interest rates, made import-substituting industries more profitable than export industries. This was the main reason for the weakness of export industries. Therefore, market liberalization policies including exchange rate and interest rate liberalization, import liberalization, and lower tariffs, were required to increase exports by selecting the technologies and production methods appropriate for the economic conditions characterized by abundant labor and inadequate capital, thereby, securing a comparative advantage in labor-intensive products.” 
31, Chang called the president to report that the goal of $\$ 120$ million in exports had been reached.

This achievement convinced President Park that an export promotion strategy could work. He therefore committed himself to that strategy. In a January 1965 address, he announced that the three highest national priorities were increasing production, increasing exports, and increasing construction. He urged the country to take exports to a new level, not only because of their economic importance in generating foreign exchange but as the best way to secure political and economic independence. The government began promoting slogans such as "exports alone promise a way to economic self-reliance" and "exports as the yardstick to measure the sum of our national strength” (KDI 2016, 432).

On Commerce Minister Park Chong-hoon's recommendation, the government upgraded a longstanding export promotion committee to a high-level export promotion and expansion committee. Its first meeting was held in February 1965; President Park presided over the twohour export promotion meetings, convened at the Blue House, the president's office and official residence, every month thereafter, until Park’s assassination, in October 1979. The meeting included representatives from government agencies (including the economic ministries, the central bank, and the Korea Trade Promotion Agency) and executives from major businesses (industrial firms, chambers of commerce, and banks and financial institutions). Its main purpose was to exchange information about the state of exports. Businesses would report on the problems they had exporting, which government officials were expected to solve. Officials would discuss various export promotion policies, including reducing red tape and improving infrastructure to facilitate exports, and report on whether export targets were being met. 
The participation of President Park in these monthly meetings demonstrated the importance and urgency of the export drive as a national goal. His presence sent a strong signal to other government officials and top business leaders about the overriding importance of increasing exports. ${ }^{54}$ The government set up "indicative targets" to encourage and pressure exporters to sell more. High export achievers received prestigious awards presented by the president himself. “The Korean government was successful in creating a social atmosphere in which contributions to exports were considered to be something good for society and even patriotic,” SaKong $(1993,39)$ notes..$^{55}$

Of course, official targets and presidential exhortations to "export more" could only go so far without concrete measures. ${ }^{56}$ The government unveiled a series of export incentives between January and March 1965 that gave a concerted push to the export drive. The most important policy was special credit for exporters at discounted interest rates. At the time, the commercial lending rate was 16.5 percent while that for exports was set at 6.5 percent, a spread that later

\footnotetext{
${ }^{54}$ In evaluating the reasons for the success of Korea's export-oriented policy, Hong $(1979,58)$ argues that “one should not fail to note that the single most important factor has been the leadership, determination, and devotion of President Park to the cause of 'nation-building by export.'”

${ }^{55}$ Cole and Lyman $(1971,190-91)$ note that "all parts of the Korean government apparatus that could be of any help work recruited for the export drive. Political leadership made it clear that performance would be judged and what an individual or an agency had contributed to the growth of exports. In a relatively authoritarian, achievement-centered bureaucracy such as Korea's, these can be powerful stimuli. ... Not only are the Korean exporters always get the immediate and close attention of the president, but the successful ones are regularly honored with merit medals. As a result, anyone who has accumulated wealth via export activities is almost considered a patriot and is assured that he has the blessings of the government. This has an immense psychological impact in a society which still caries remnants of traditional Confucianism. This honor and encouragement bestowed on exporters has undoubtedly helped channel the best of the entrepreneurial class in Korea into export activities."

${ }^{56}$ As Krueger $(1979,98)$ notes, "The targets were implemented in a variety of ways. In the first instance, fulfillment was the responsibility of the Ministry of Commerce and Industry, and an 'export situation room' was established to monitor export performance. Targets were signed to industrial associations, firms, and regions on exports were at or above their target levels, few changes were initiated. If, however, exports begin lagging for particular sector, efforts were initiated to rectify the situation. Measures extended all the way from the threats (and presumably implementation) of sanctions to provision of additional incentives and government measures to remove bottlenecks.”
} 
grew. ${ }^{57}$ The government also introduced "wastage allowances"-allowing exporters to import more raw materials and intermediate goods than needed for exports, allowing them to resell the extra amount at a premium in the domestic market—as another way of increasing the profitability of exports. These incentives were provided in a neutral matter across all exporting industries. All exports were considered good and policymakers adhered to what Krueger and Yoo $(2002,608)$ called an "export theory of value.”

The United States, which had always wanted Korea to export enough to pay for its imports and end its dependence on American aid, strongly encouraged these efforts. The relationship between the Korean government and US economic advisers improved dramatically after the May 1964 devaluation and cabinet shakeup. Policy changes in Korea, and personnel changes on both sides, helped create a new atmosphere of collaboration, and the relationship shifted from antagonism and criticism to cooperation and encouragement. On the Korean side, the cabinet reshuffle that brought Chang Ki-young to power also led to the replacement of military officials with civilian technocrats in economic positions, many of whom had been educated in the United States (Cole and Lyman 1971). ${ }^{58}$ In August 1964, Joel Bernstein, who had earned a Ph.D. in economics from the University of Chicago in 1956, replaced James Killen as USOM director. The new US team was less concerned about stabilization, such as meeting inflation targets, and more interested in longer-term structural reforms. ${ }^{59}$ With Korea having

\footnotetext{
${ }^{57}$ As a report by the Korea Development Institute (KDI 2016, 107) indicates, "An almost unlimited supply of shortterm credit to exporters at such a preferential interest rate was an enormous incentive for exporters in the economy in which credit was tightly controlled by the government and access to banking institutions was not easy.”

${ }^{58}$ Brazinsky $(2007,132)$ reports that "under intense pressure from the United States, the Park government replaced many of its more nationalistic economic advisers who came from military backgrounds with civilian economists, many of whom were Western trained and who worked well with American advisers in Seoul.”

59 The USOM built up a strong team of advisers to work with their Korean counterparts in formulating economic policies. The brought in leading American academic economists as short-term consultants, including Edward Shaw and John Gurley from Stanford and Hugh Patrick from Yale on financial sector development. Other advisors included Richard Musgrave on tax policy, Peggy Musgrave on trade policy, Ronald McKinnon on tariff policy, Robert Aliber on exchange rate policy, and Gustav Ranis and John Fei on labor market policies.
} 
devalued its currency and begun to focus on exports, the two sides were in basic agreement about the direction of Korean policy. As a result, the US stance changed from one of withholding aid to force Korea to change its policy to offering additional aid when Korea moved in a direction that the USOM team approved. ${ }^{60}$ The US advisers and Korean officials forged a close partnership on economic policy. ${ }^{61}$

In particular, the United States welcomed the government's efforts to boost exports. For three years, Amicus Most, an American consultant hired by USOM, worked on export promotion in Korea. He believed that "correcting the balance of payments situation is of such paramount importance that a major effort to increase exports is essential” (Most 1966, 1). ${ }^{62}$ US advisers did not object even to some unorthodox policies, such as the low interest loans to exporters. ${ }^{63}$ President Park and his top economic leadership were thus united in their determination to increase exports. With US advice and assistance, the Koreans formulated the policies to do so

\footnotetext{
60 "Instead of berating them for their incompetence, we began to encourage their best efforts and praise their accomplishments. Instead of insisting on better performance on their part so that US assistance could be reduced, we said that 'if you will do more we will try to do more and get others, such as the Japanese and Europeans, to contribute more also,"” David Cole testified (US House of Representatives 1978, 45). See also Cole (2014). 61 "The EPB's building was next door from the USOM in downtown Seoul, and the geographic proximity of the two institutions facilitated interaction between their personnel," writes Brazinsky $(2007,142)$. "The assistant director of the EPB credited American advisers with introducing concepts such as present value and the floating exchange system 'to the extent that we were adept and skilled it was from the beginning because we were next to our family teacher the USOM.' One American called them 'blood brothers.”'

62 "Korean businessmen had little or no contact with the outside world, and were unfamiliar with markets, market research, and methods of doing business abroad," Most $(1966,5)$ reported. "Korean industry, with some exceptions, was inexperienced in the requirements of quality, design, packaging, specifications and price that would enable them to compete internationally." Most introduced Korean exporters to potential foreign buyers and helped educate them about how to produce the higher-quality products that were in demand in foreign markets.

${ }^{63}$ According to Cole $(2014,157)$, Bernstein invited his friend Amicus (Mickey) Most to advise the Koreans on export promotion. "Mickey worked with the Ministry of Commerce and industry to formulate a program that called for quickly available low interest bank loans and easy access to raw materials for exporters as a stimulus especially to manufactured exports. When I went over to the Ministry of Finance to meet with the minister and senior staff to discuss the proposed program I asked if they had any problems with it they indicated that they did not. ... I later learned that the Ministry of Finance was surprised that we had approved to low interest loan aspect. They had counted on us to reject it, as the previous USOM leadership would have done, and so rather than taking a position that might be unpopular with the president or the DPM they have not indicated their opposition to me. ... I personally believe that an all-out program to promote exports was a good thing for their next few years and that credit and raw material provisions were key components of its success.”
} 
and implemented them. ${ }^{64}$ The growth of exports after the 1960-61 and 1964 devaluations gave Korean officials confidence that sustained export growth was possible. As Yoo $(2020,23)$ points out, at least in the beginning, export growth led to the adoption of the export promotion policy, not the other way around.

\section{Foreign Exchange and Import Liberalization}

The export drive was relatively uncontroversial; the process of opening up the foreign exchange market and easing import restrictions was much more politically sensitive and therefore more contentious. This process was drawn out over four years, 1964-67.

In his memoirs, Kim $(1994,39)$ explains how he, as deputy minister of commerce and industry, helped simplify the foreign exchange allocation system:

"I started by canceling the export-import link system that was in effect at the end of 1964 .

Next, I increased the number of automatically approved import items, which stood at zero in June 1964, to 8.0 percent of total items approved for import during July-December 1964 and to 62.7 percent in December 1965. I delegated the administration of import approval to the Bank of Korea. In November 1964 I eliminated many import quota items to lay a foundation for the single floating exchange rate. Finally, in January 1965, as a preliminary measure for the implementation of the floating exchange rate, I eliminated outdated policies, including export subsidies, the import-export link system, and the

\footnotetext{
64 "Rather than a product of foreign technical advice, the national export promotion drive was a result of internal Korean perceptions of their need to become economically independent and to avoid too much reliance on the United States," Steinberg $(1982,99)$ notes. Bernstein emphasized the following point: "No one but Koreans could or did do the job-from the establishment of policies and programs through their execution. The United States did, however, provide financial, technical, and moral support that was a critical factor in encouraging and supporting Korean actions. Such supportive action by a foreign agency can only succeed in its purposes if there is a wide measure of common understanding and support for the operational goals involved and also adequate levels of mutual confidence” (US House of Representatives 1978, 41-42).
} 
barter system with the exception of barter specified in trade treaties. The floating exchange rate was finally implemented on March 22, 1965, when the conditions were deemed right.”

A slew of regulations and previous policies of import repression, all motivated by the need to conserve foreign exchange, were swept away or relaxed in moving toward a more open (if still restricted) system related to foreign exchange. Even so, US officials believed that Korea was moving too slowly toward a flexible exchange rate after the 1964 devaluation (Joo 2017). The IMF provided technical assistance to facilitate the transition and approved \$9.3 million in standby credit at the time of the devaluation.

In March 1965, the government unveiled an open market for foreign exchange certificates and the adoption of a flexible exchange rate, which had been promised a year earlier. Under the system, exporters would turn over their foreign exchange earnings to the Bank of Korea and receive certificates of equivalent value that were fully tradable at a market-determined rate.

The price of exchange certificates immediately depreciated from 255 to 272 won per dollar. The black-market premium completely disappeared (see figure 1). The government announced that the won could depreciate further but would not be permitted to appreciate (i.e., fall below 255 won per dollar). However, the government never really accepted a pure floating rate and soon intervened to stabilize the exchange rate at 270 won per dollar. It did not, however, return to a hard peg, allowing the won to depreciate steadily in line with higher Korean inflation. Under the new system, exporters could retain or sell all of their foreign exchange earnings at a competitive exchange rate. The move marked a big change from the export-import linkage in which only exporters had access to a limited amount of foreign exchange at an 
overvalued rate. Henceforth, exports were to be promoted by indirect policies, including easy access to credit, duty-free imported raw materials, and tax exemptions rather than export subsidies or preferential access to foreign exchange, both of which were abolished.

As a result, the government no longer regulated imports by controlling the allocation of foreign exchange; the quarterly foreign exchange budgets, which made allocations to particular importers for particular products and amounted to specific quantitative restrictions on imports, were no longer necessary. ${ }^{65}$ Jones and SaKong $(1980,96)$ argue that the change in incentives that came with ending privileged access to foreign exchange was an important factor behind the acceleration in economic growth:

"If you can make 100 percent in a few months with little risk, through privileged access to foreign exchange, there is little point in devoting effort to the difficult and complicated task of exploring export markets and putting together internationally competitive productive combinations. The exchange rate reforms closed out the zero-sum sources of rent, reduced opportunity costs, and drove rent-seekers into productive positive-sum activity." 66

As Cole and Lyman $(1971,89)$ put it, the simplification of the foreign exchange regime “signaled the government's willingness to provide incentives and opportunities for the private sector as a whole and to dismantle the complex set of controls and licensing system that had played such an important part in the corruption of government and business under the Rhee

\footnotetext{
65 “Since import control by QRs [quantitative restrictions] had tightened severely during the previous two years of foreign exchange crisis, the initial loosening in 1965 was not much more than a return to the pre-1963 level of import control," notes Kim (1991b, 46).

${ }^{66}$ The new policies changed the rules of the zero-sum game under the Rhee government, "with the elite seeking access to the limited foreign exchange that would allow them to become wealth"; under Park "it was a positive-sum game, because there was a virtually unlimited supply of investment opportunities” (Steinberg 1982, 98).
} 
regime. ${ }^{{ }^{67}}$ As a result, the incentives for business activity shifted from securing rents to earning profits. These administrative policy changes had large incentive effects for exports.

Initially, major businesses denounced the exchange rate reform. "When the exchange rate reform was announced in 1964, some in the business community, particularly powerful, large business groups, expressed opposition to the reform," Kim (1991c, 107) notes. “Although both export and import-substitute industries could gain by the devaluation, the large business groups opposed it because they preferred to operate under extensive controls rather than under a realistic exchange rate and relatively free-market situation.”

Under normal circumstances, the Ministry of Commerce and Industry might have been expected to resist reform because of its close ties to businesses that benefited from the status quo and feared import liberalization. But the top economic officials rarely consulted business in making key decisions and largely ignored these concerns. ${ }^{68}$ To the extent there was a problem it was within the bureaucracy. Kim $(1994,40)$ recalled his efforts to explain the rationale for the more open policies and change attitudes of staff at the Ministry of Commerce and Industry:

"I was filled with a sense of accomplishment practicing those policies I believed in. To solve the inherent conflicts [within the ministry] I held directors’ meetings every morning, explaining to them the background theories for trade liberalization as well as the founding motives, goals, and functions of the International Monetary Fund and

\footnotetext{
67 “The restrictive system of import quotas and the manipulation and control of scarce banking resources had together formed the backbone of a mutually corrupting and mutually profiting system of cooperation between a limited number of businessmen and government officials," Cole and Lyman (1971, 93) note. "In the reforms of 1964 and 1965, both of these systems collapsed, to the vain cries and behind-the-scenes maneuvering of those who had long lived by them."

${ }^{68}$ As Brazinsky $(2007,142)$ notes, "US and Korean economists made crucial decisions about economic policies with little or no popular input.”
} 
the General Agreement on Tariffs and Trade. I emphasized that we needed to take a step toward liberalization despite the uproar within the business sector.”

The 1965 initiatives — the depreciation of the won, the more open foreign exchange market, the provision of cheap credit to exporters—-helped push exports from \$120 million in 1964 to $\$ 175$ million in $1965 .{ }^{69}$ While it is difficult to quantify the impact of each policy change, much of what was done in 1964-65 was simply improving the incentive to export. ${ }^{70 \text { "The export }}$ success of the 1960s and 1970s was basically due to the removal of impediments to trade, namely, the complicated foreign exchange system and the negative effects on export of the protectionist import policy,” Yoo $(2020,27)$ concludes. “Once the impediments were removed, the economy began realizing its huge export potential, which had been left unexploited until then."71

Two other major policy changes in 1965 supported the export drive: the normalization of relations with Japan and the liberalization of interest rates. Both were unpopular at home but supported by US advisers. Both ultimately proved beneficial to the Korean economy. In June 1965, Korea concluded an agreement with Japan to normalize diplomatic relations. As a result, bilateral trade grew rapidly, and Japanese loans and investments gave

\footnotetext{
${ }^{69}$ The range and destination of Korean goods sent around the world also expanded. For example, in 1960, South Korea exported 65 products to 20 countries. Five years later, it exported 621 products to 76 countries. In those five years, the share of manufactured exports in total exports rose from 18 percent to 62 percent (Most 1969). ${ }^{70}$ Cole and Lyman $(1971,191)$ note, "It is difficult to estimate the real value of the various export incentives and even more so the significance of direct government efforts to promote exports. The combination of low interest rates, easily obtained loans, no restriction in imported inputs, tax exemptions and reduced public utility rates, which are available to the exporter producer, would all have to be compared with the actual or imputed costs incurred by nonexporters. These are not accurately measurable. Any result would most likely be misleading and less useful than a simple suggestion that the incentives and encouragement given to exports were sizable and effective."

${ }^{71}$ Krueger $(1979,115)$ agrees that Korea's exports were so suppressed that they had vast potential to increase: "by $1960, \ldots$ Korea's exports were abnormally low relative to her size and stage of development. In that sense, there was something of an 'export potential' waiting to be tapped. That potential provided a reservoir from which initial spurts in exports could occur in response to the incentives offered to them.”
} 
Korea access to more foreign exchange. The United States had long supported this step and rewarded Korea with \$300 million in additional aid and \$200 million in credit assistance.

In September 1965, Korea lifted interest rate controls that had depressed savings and financial development. The cap on deposit rates was lifted from 15 percent to 30 percent and that on loan rates was raised from 16 percent to 26 percent, though the rate on export credit remained 6.5 percent. The result was a dramatic increase in private savings, which were channeled through the banking system and produced an astonishing increase in investment that further propelled exports. Gross domestic investment rose from 15 percent of GDP before the reform to more than 25 percent of GDP after, reaching nearly 30 percent by $1969 .{ }^{72}$

Further trade policy changes came in 1966. When Kim became minister of finance in January of that year, he sought to reduce tariffs and gain Korea’s admission to the General Agreement on Tariffs and Trade (GATT). Korea's tariff code had not been revised since the 1950s, because duties had not been an important source of revenue or a way of protecting domestic industries. However, as the quantitative controls on imports were eased, tariffs became more important. Here, US advice ran up against strong domestic opposition and was not ultimately taken. Ronald McKinnon of Stanford University, on contract from USAID, proposed a uniform across the board tariff of 20 percent, with a limited number of industries protected at 90 percent. Domestic industries, particularly in agriculture, protested that such a step would bring irreparable harm; exporters did not push for tariff reductions, because they already had

\footnotetext{
${ }^{72}$ See Kim (1991c, 152). Westphal and $\operatorname{Kim}(1982,215)$ argue that "these reforms were instrumental in financing the higher investment rates required to accelerate GNP growth.” The financial reform originated in a report from three leading US academics—Edward Shaw, John Gurley, and Hugh Patrick. Their June 1965 report recommended raising interest rates and relaxing credit controls. A meeting between Edward Shaw and Chang Ki-young in late September 1965 helped convince Chang to endorse the recommendations. He then sold these ideas to the president and the National Assembly, and the reforms were implemented by the end of the month (see Cole and Park 1983).
} 
duty-free access to foreign-produced inputs. Opposition by business groups led to a stalemate in the interagency tariff-setting process, and duties were reduced only slightly. ${ }^{73}$

Korea also gained admission to the GATT, ensuring that it had nondiscriminatory, mostfavored nation (MFN) trading status in other markets. The decision to seek admission encountered strong resistance from the Agriculture-Fishery Committee in the National Assembly, but the cabinet approved the application in May 1966 (Shim 2010). It then took nearly a year to win approval from other countries. Although questions were raised about Korea’s import restrictions, the contracting parties of the GATT did not require any specific changes in Korea’s trade regime as a condition of entry, and it officially joined in May $1967 .{ }^{74}$ After serving as finance minister from January to September 1966, Kim was appointed minister of commerce and industry from March 1967 until October 1969, during which time he oversaw an incremental liberalization of imports. In July 1967, the ministry shifted from a “positive list” system of import control (in which most imports were restricted or prohibited unless specifically allowed) to a "negative list” (under which most imports were allowed unless specifically restricted or prohibited). The number of automatically approved imports had progressively increased from 1965 to 1967, leading up to the adoption of the negative list (Kim

\footnotetext{
${ }^{73}$ The duties on nondurable consumer goods fell somewhat, from 74.2 percent in 1966 to 43.2 percent in 1967 (Kim 1991b). As a result of this political pressure, the tariff decline that the government was able to undertake was very modest. However, because so many importers were exempt from tariffs, the formal rates give a misleading indication of the tax burden on those purchasing imported goods. The average tariff collected fell from 46 percent in 1960 to 9 percent in 1966, mainly because of the elimination of a foreign exchange tax and tariff exemptions and rebates. (Frank, Kim, and Westphal 1975). "The clear distinction between imports for export production and imports for domestic use. The former were allowed freely so as to ensure the ability of domestic exporters to compete in the international market. The latter were strictly controlled prioritized and frequently made conditional upon a contribution to the national export drive," notes Luedde-Neurath (1986, 87).

${ }^{74}$ A delegation was sent to Geneva to negotiate with other countries over admission. The Korean government was so poor that the delegation lacked enough money to buy three meals a day. It was not possible to approach the GATT members freely to establish networks without any money. The task force team therefore asked the Korean government to send it money to develop social connections with GATT members. After President Park heard this request from his aides, he told them to advance his salary and sent it to the delegation (Shim 2010).
} 
1991b). In July 1966, the authorities increased the number of commodities under the automatic licensing category from 1,450 to 2,259, reducing the scope of restricted imports. The number of automatically licensed goods rose from about 30 percent in 1964 to 79 percent in 1965 and then to 84 percent in the 1966 program. The positive list consisted mainly of essential raw materials, energy products, and capital and intermediate goods.

Figure 2 shows the discrete jump in the share of imports subject to automatic approval in 1966-67 and the relatively unchanged level of duties. However, the shift to a negative list did not constitute a radical change in import policy, increasing imports by only about 5 percent, to $\$ 27$ million in the final five months of 1967 and \$68 million in 1968 (Brown 1973). The decision nevertheless encountered stiff domestic opposition. “Large parts of Korea’s business community and bureaucracy reacted strongly against the liberalization plan,” Brown $(1973,156)$ recounts. “No one wanted protection for his industry lowered, of course, and those businessmen benefiting most from protection banded together to oppose any extensive liberalization.” There was an extensive public debate about how quickly Korea should expose protected industries to foreign competition. 
Figure 2

Average tariff and share of automatically approved imports in South

Korea, 1955-70

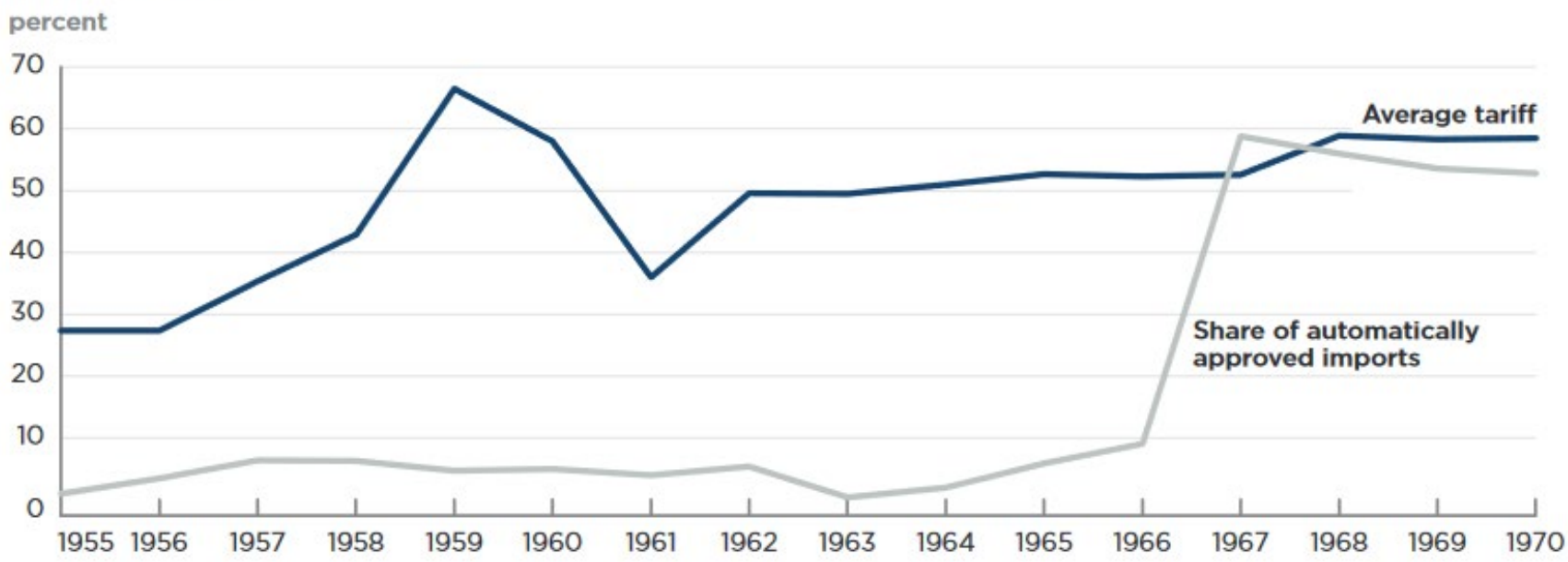

Source: Kim (1991b), cited in Yoo (2017).

In sum, Korea completely changed the direction of its commercial policy between 1964 and 1967, from import controls to export promotion. Its policy changes included establishing a realistic exchange rate and a market in foreign exchange, which enabled the government to dispense with the old system based on an overvalued exchange rate and associated policies of foreign exchange rationing, export subsidies, and import repression. Joel Bernstein, the director of the US economic mission in Korea from 1964 to 1967, described the process as "a radical shift from a typical ‘closed economy’ characterized by pervasive market shortages, tight import, licensing and quantitative restrictions, tight credit rationing, and various other direct economic controls to a relatively open economy in which most of these direct controls were swept away."75

\footnotetext{
75 "This was essential for a number of reasons, which included the need to allocate limited productive resources more efficiently; to provide greater opportunities for small businessmen to gain access to raw materials and credit; to reduce the corruption and sapping of morale and initiative that is typically associated with large scale licensing; to strengthen competitive pressures for increasing productivity and pursuing imports rather than concentrating entrepreneurial attention on getting licenses needed to operate; and to help control inflation” (Bernstein, testimony in US House of Representatives 1978, 41-42).
} 
At the same time, the government provided abundant credit to exporters and enforced export discipline.

The shift toward export orientation involved unshackling exports rather than liberalizing imports, at least imports that were not used for exports. Korea did not significantly open its domestic market to foreign competition. Although it imposed few restrictions on the importation of raw materials, intermediate goods, and capital goods and equipment for domestic producers and exporters, other imports for the domestic market—particularly finished consumer goods— remained tightly controlled. ${ }^{76}$ The liberalization process was a managed one in which importation was often linked to export performance. As Westphal (1990a, 58) notes: "Import liberalization was not an important element of the reforms that put Korea on the path of export-led development. But the rules of the importing game were nonetheless radically changed. Prior to the reforms, rent seeking in relation to import licensing and tariff exemptions had provided a major source of revenue for businessmen and government officials alike.”

With the reforms of the mid-1960s, the import regime that was rife with rent-seeking was gone and exporting was a rewarded activity.

\section{The End of Reforms}

The reforms of 1964-65 began a remarkable transformation of the Korean economy, including rapid export growth and industrial development, particularly in labor-intensive

\footnotetext{
${ }^{76}$ As Westphal (1990a, 44) notes, export promotion was not achieved "by the conventionally prescribed approach, which is to reduce greatly (if not eliminate) the domestic market's insulation from import competition. Instead, they accomplished it by insulating export activity from the otherwise adverse consequences of policies motivated by other concerns. A virtual free trade regime for export activity was established, so that capital and intermediate inputs used in export production could be imported without tariffs and outside the quotas which applied to imports for other purposes; regardless of their source, tradeable inputs were exempt from indirect taxes.”
} 
manufactured goods. By 1967, in stark contrast to the despair of 1963-64, the Korean economy was growing rapidly. The country's economic success translated into political success for President Park, who was reelected president in a landslide in May $1967 .{ }^{77}$

The foreign exchange situation improved dramatically, and shortages were no longer a constraint on growth or a concern for policymakers. Foreign exchange reserves rose thanks to the expansion of exports, an increase in remittances from Korean workers in Japan, and increased inflows of foreign capital. The percentage of imports financed with Korean foreign exchange rose from 30 percent in 1964 to 79 percent in 1965 and 84 percent in 1966 (IMF 1966), giving the government to freedom to operate without dependence on US aid or the advice that came with it.

Partly for this reason, 1967 also marked the end of economic reform. The reform team, which had been assembled three years earlier, fell apart when Chang Ki-young was dismissed as deputy prime minister in October. The driving force behind the reforms, Chang alienated many groups inside and outside government and eventually fell out with President Park. ${ }^{78}$ Still, he lasted more than three years in that crucial position, providing continuity at a time when the norm was a rapid turnover of officials. On the US side, the Bernstein USOM team dissolved, as personnel were assigned to other countries. With Korea no longer as dependent on the United States, the influence of US advisers became much weaker.

\footnotetext{
77 "Park had staked his political legitimacy on economic growth, and by producing it he created a compelling reason for the public to support him,” Brazinsky $(2007,148)$ writes.

78 "Chang's authoritative and unusual leadership style and his disregard for the internal order of the public service gave many public officials a hard time. Consequently, sentiment against Chang grew," according to a KDI report (2016, 182). His colleagues gave him a plaque that read "The EPB men will remember your 1,241 days of hard work and no rest." President Park intervened twice, in 1965 and 1966, to stop "no confidence" votes against him in the National Assembly. When he began to fight with the president, however, he was let go.
} 
An explosion of imports also contributed to the end of reform. Although exports were growing rapidly, imports grew even more rapidly, soaring from less than 15 percent of GDP in 1964 to more than 20 percent of GDP in $1968 .{ }^{79}$ By 1968 , the merchandise trade deficit had grown to nearly 15 percent of GDP (figure 3). The gap was no longer financed by American aid but by massive foreign loans, which Korea now found easily accessible. (Korea did not record a trade surplus until 1986.) The capital inflows led to an expansion in domestic credit, which led to more inflation. With the government adjusting the value of the won at less than the rate of inflation, Korea's currency strengthened in real terms. By one estimate, it was overvalued by about 9 percent in 1968 (Westphal and Kim 1982).

Some segments of the business community pointed to the rapid growth in imports and opposed any further steps to open the domestic market. ${ }^{80}$ The government's failure to maintain a competitive exchange rate was another factor preventing additional import liberalization.

Resistance to depreciation also remained strong, not based on the old argument that it would increase inflation but on the new grounds that it would make it difficult for firms and banks to service their burgeoning foreign debts. ${ }^{81}$

\footnotetext{
${ }^{79}$ On Export Day in 1969, President Park announced that "the government will achieve at any cost the $\$ 1$ billion export goal” in 1970 (Kim 2004, 117). The \$1 billion target was reached, an incredible achievement given that just six year earlier the goal had been $\$ 100$ million. Nontraditional export items accounted for less than 0.1 percent of exports in 1961 but had grown to comprise 42 percent of exports by 1970 (Yoo 2020).

${ }^{80}$ USAID official Gilbert Brown $(1973,145)$ thought that monthly export meetings "increased the exposure of the president to special pleading by business grounds ... and may partly explain why Korea moved away from liberalization and a realistic exchange rate from late 1967 until mid-1969.”

${ }^{81}$ According to Kim (1991a, 132), "This failure to make progress in import liberalization was at least partly attributable to the unsatisfactory performance of exchange-rate management by the government.”
} 
Figure 3

South Korea's exports and imports as a share of GDP, 1953-75

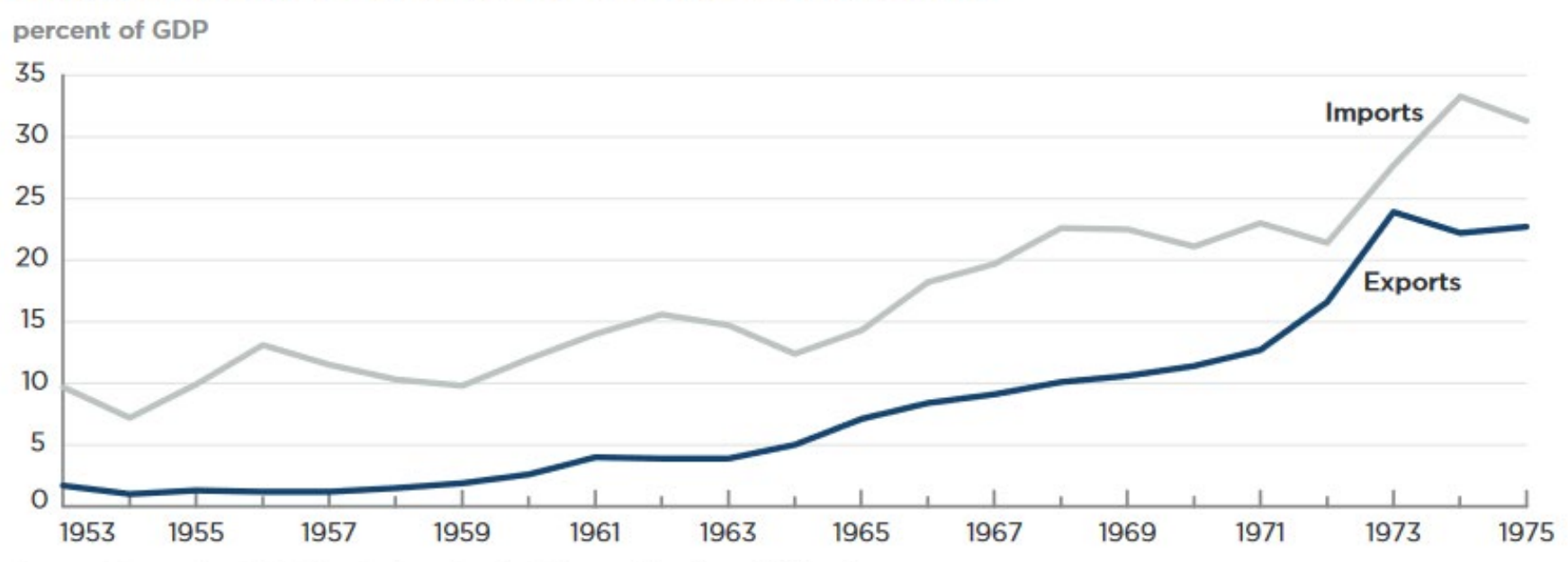

Source: Economics Statistics System, Bank of Korea, http://ecos.bok.or.kr.

In the 1964-65 transition period, the key policy changes were the devaluations, the intensification of export incentives (particularly through the provision of credit and reduction in taxes on exporters), the creation of an open foreign exchange market, the partial liberalization of imports, and the liberalization of interest rates. Not everyone believes that these policies were important, however. In her 1989 book Asia's Next Giant: South Korea and Late

Industrialization, Alice Amsden argues that government intervention and "getting prices wrong” (through protectionism, subsidies, and coercion) were critical factors behind Korea’s industrialization. "In or around 1965, the Korean won was devalued, interest rates were raised, tariffs were lowered, and taxes were increased,” Amsden (1989, 141) acknowledges. But she views these policy changes as being unimportant for the growth that followed. In her view, "the logic driving Korean industrialization was not the freeing of markets” and "liberalization amounted to nothing more than a footnote to the basic text of Korean expansion.”82

82 'If one believes that Korea began to grow rapidly in the 1960s as a result of 'liberalization,' then its adoption of relatively freer prices must be attributed to an embrace of market theory by Korean policymakers, coached by foreign experts. Yet an examination of cotton textiles suggested that the policy regime that Korea eventually adopted 
This assessment is not accepted by most scholars of the Korean economy of the 1960s. Larry Westphal (1990b, 1736), a leading Korea expert who is sympathetic to the idea that industrial policy promoted economic growth, responded: "My knowledge of the Korean economy does not in any way support this interpretation.” For example, in concluding that government intervention was the key factor behind the country's industrialization, Amsden believes that exchange rates were unimportant. "In Korea, exchange rates were not grossly distorted, but they did succeed in stimulating exports only when they operated in conjunction with other policies,” Amsden $(1989,144)$ asserts. "Exports have been heavily subsidized and coerced, so inside the range of reasonableness, the relative price of foreign exchange has been altogether irrelevant.” The statement that the exchange rate was not grossly distorted must refer to the periods after the 1961 and 1964-65 devaluations, not before 1961 or in 1963 when they were highly distorted (see figure 1). Her book does not discuss the period before 1961, when the overvalued won posed an insurmountable obstacle to most exports. ${ }^{83}$ As Westphal $(1990 \mathrm{~b}, 1736)$ points out in his review, "The book has many more perceptive things to say about what drove Korea's industrialization in the 1970s and 1980s than it does about what caused its takeoff in the early 1960s, when neither the chaebol nor heavy industry were prominent.”

The reform era of 1964-67 was also not a period in which industrial policy - selective support for particular industries - was a prominent feature of Korea’s approach to trade. That

evolved out of a complex process in which the interests of opposing groups were reconciled, not out of theoretical conviction," Amsden $(1989,78)$ writes. "Therefore, it may be said that growth has been faster in Korea not because markets have been allowed to operate more freely but because the subsidization process has been qualitatively superior.” In her view, "to attribute Korea's growth and industrialization to these market-policies rather than the government's dual policy of discipline and support is to misrepresent a fundamental property of the most successful cases of late industrialization."

${ }^{83}$ Westphal (1990a, 45) argues that "the most important incentive [for exports] apart from the exchange rate was the virtual free trade regime [for exporters], which accounted for more than two-thirds of total export incentives in 1968” (emphasis added). 
term becomes more appropriate with the launching of the Heavy and Chemical Industry (HCI)

drive in 1973, which channeled capital investment into the production of iron and steel,

nonferrous metals, shipbuilding, machinery, electronics, fertilizers, oil refining, and cement.

These industries were much more capital intensive than the labor-intensive industries that had

emerged as Korea’s main exports in the 1960s and 1970s. President Park may have wanted to

promote heavy industries ever since he attempted to do so in 1961-63; he had the opportunity to

do so in the early 1970s without American interference, ostensibly on grounds of national

security (Horikane 2005).

The role of industrial policy in Korea's development has been controversial. Many

Korean economists believe that excessive capital investment was forced into heavy industry, leading to the stagnation of Korea's labor-intensive manufactured exports. ${ }^{84}$ The problems associated with the HCI drive led to its abandonment in 1979. Other observers, such as Amsden, argue that industrial policy was the key to Korea's industrialization in the 1970s and 1980s. This paper does not address the debate over industrial policy, as its main purpose is to examine the origin of key policy changes of the mid-1960s that contributed to Korea's export orientation.

\footnotetext{
${ }^{84}$ The HCI "scarred the Korean economy for years," according to Nam $(1995,162)$, because it created excess capacity in unprofitable industries while depleting investment funds that could have been used to support other exporting industries. (By 1979, the HCIs accounted for almost 70 percent of fixed investment.) The government also relied on foreign borrowing to finance investment and consumption. As a result, external debt grew from $\$ 16.8$ billion in 1978 to $\$ 40.1$ billion in 1983 (Nam 1995). Stern et al. $(1995,190)$ ask, "Did the government’s industrial policy of the 1973-78 period do better than what an unfettered market economy might have accomplished? The answer would appear to be no.” Auty (1992) argues that the HCI was useful for technological catch-up but strained implementation capacity by trying to do too much. For a more favorable assessment, see Kim (2019). Lane (2019), Choi and Levchenko (2021), and Kim, Lee, and Shin (2021) provide recent quantitative assessments of the HCI drive on Korea's economy.
} 


\section{Conclusions}

Throughout the 1950s, an overvalued exchange rate suppressed South Korea’s exports and led to foreign exchange rationing for imports. Firms had little incentive to export and earn foreign exchange; rather, there was a large financial gain to be had in obtaining obtain import permits and foreign exchange from the government to purchase cheap imports and sell them at high prices in the domestic market. This process amounted to classic rent-seeking and was rife with corruption and graft.

The chronic shortage of foreign exchange due to the overvalued exchange rate meant that Korea could only import as much as it did because of massive US aid. The United States wanted to reduce Korea's dependence on foreign assistance and enable the country to become selfsustaining, in the sense of earning enough foreign exchange from exports to pay for its imports. Toward that end, the United States consistently pushed successive governments to devalue the won and liberalize its foreign exchange controls.

When the military government of Park Chung-hee came to power, it shared the US objective of Korean self-sufficiency but initially struggled to achieve that objective. Under duress from a potential famine in 1963-64 with food aid being withheld by US authorities, Korea finally began to alter its trade and foreign exchange policies. ${ }^{85}$ It initiated the shift away from a closed, aid-dependent economy with a major devaluation in May 1964, after which a new reform team led by Chang Ki-young seized upon the newly emergent possibilities for export growth and pushed forcefully for a broad range of export promotion and import liberalization measures.

\footnotetext{
${ }^{85}$ As Cole later testified, "It is my belief that this experience in 1963-64 convinced the Koreans they should broaden their sources of support and reduce their overwhelming dependence on the United States” (US House of Representatives 1978, 45).
} 
The cornerstone of the new export promotion stance was maintaining a realistic exchange rate, a policy augmented by low interest loans and reduced taxes for exporters, easy importation of raw materials, intermediate goods, and machinery needed to produce exports, and the removal of many bureaucratic obstacles to exporting. ${ }^{86}$ These incentives were not selectively applied to targeted industries but generalized to all exporters as long as they proved capable of selling abroad and earning foreign exchange. However, it was not a liberalization in the sense of removing all controls and price distortions or allowing foreign firms to compete in Korea's domestic market.

These policy changes marked an historic turning point in Korea's economic development. Despite the rapid growth that ensued, the policy changes were bitterly opposed at the time, especially by those businesses that had benefited from the old system of discretionary government allocation of import licenses.$^{87}$ Yet the Korean policymakers were insulated from these political pressures and largely ignored the complaints. The support of Park Chung-hee was crucial to the government's strong commitment to the policy. He embraced export promotion both as a way to achieve rapid economic development and also as a way to gain economic independence and reduce dependence on US aid, and its susceptibility to US economic pressure and interference in its domestic affairs.

The Korean story is a fascinating one for what it reveals about the underlying nature and causes of this often-cited transformational policy change. Discussion of Korea's policies has

\footnotetext{
${ }^{86}$ A critical part of East Asia’s economic success, as Hughes (1988) put it, was unshackling exports that they themselves had shackled.

87 "The reform and redirection of economic policy were carried out amidst strife and opposition, over the often loud cries of special interest groups, and in the face of continuing and widespread pessimism and mistrust," Cole and Lyman (1971, 92-93) recall. "Almost every major economic reform of this period encountered doubt and skepticism at the outset."
} 
sometimes become embroiled in debate over whether policymakers were following standard neoclassical economic prescriptions or a heterodox mix of liberalization and state intervention. At least initially, the most important policy reform was simply eliminating an overvalued exchange rate to give firms an incentive to export and allowing exporting firms access to inputs at world prices, even if the domestic market was still protected. But this was accompanied by other interventionist measures that distorted prices and provided additional strong incentives to all exporters.

The views of the main parties, the Korean and US governments, were initially divergent as to the path that economic policy in Korea should take. The Korean authorities wanted to get out from under American dominance and intervention while the US authorities wanted to reduce the level of grant assistance to Korea. When exports rose significantly after the initial devaluation in 1961, both the Korean and US authorities gradually began to see the benefits of an export-led economic development strategy. Their interests converged on the set of policy measures that reinforced that strategy and their relationship moved from antagonism and conflict to agreement and cooperation. 


\section{References}

Amsden, Alice H. 1989. Asia's Next Giant: South Korea and Late Industrialization. New York: Oxford University Press.

Auty, Richard M. 1992. The Macro Impacts of Korea’s Heavy Industry Drive Re-evaluated. Journal of Development Studies 29: 24-48.

Bates, Robert H., and Anne O. Krueger. 1993. Generalizations Arising from the Country Studies. In Political and Economic Interactions in Economic Policy Reform: Evidence from Eight Countries, ed. Robert H. Bates and Anne O. Krueger. Cambridge: Blackwell.

Berger, Samuel D. 1966. The Transformation of Korea: 1961-1965. Samuel D. Berger Papers, MS-845, Box 1, Folder 9. American Jewish Archives, Cincinnati, Ohio.

Brazinsky, Gregg Andrew. 2005. From Pupil to Model: South Korea and American Development Policy during the Early Park Chung Hee Era. Diplomatic History 29: 83-115. Brazinsky, Gregg Andrew. 2007. National Building in South Korea: Koreans, Americans, and the Making of a Democracy. Chapel Hill, NC: University of North Carolina Press.

Brown, Gilbert. 1973. Korean Pricing Policies and Economic Development in the 1960s. Baltimore, MD: Johns Hopkins University Press.

Cho, Lee-Jay. 2019. Role of the United States in the Economic Development of Korea. In The Park Chung Hee Era: Economic Development and Modernization of the Republic of Korea, ed. Lee-Jay Cho. Honolulu: University of Hawaii Press.

Cho, Jaedo, and Andrei A. Levchenko. 2021. “The Long-Term Effects of Industrial Policy.” NBER Working Paper No. 29263, September.

Cole, David C. 2014. Lucky Me: Engaging in the World of Opportunity and Challenge. Self published.

Cole, David C., and Princeton N. Lyman. 1971. Korean Development: The Interplay of Politics and Economics. Cambridge, MA: Harvard University Press.

Cole, David C., and Young C. Park. 1983. Financial Development in Korea, 1945-1978. Cambridge: Harvard University Press.

Connolly, Michelle, and Kei-Mu Yi. 2015. How Much of South Korea's Growth Miracle Can Be Explained by Trade Policy? American Economic Journal: Macroeconomics 7: 188-221. Cronk, Edwin. 1998. Foreign Affairs Oral History Project, The Association for Diplomatic Studies and Training. Available at http://www.adst.org/OH\%20TOCs/Cronk,\%20Edwin.toc.pdf. 
Frank, Charles R., Jr., Kwang Suk Kim, and Larry Westphal. 1975. Foreign Trade Regimes and Economic Development: South Korea. New York: Columbia University Press.

Haggard, Stephan. 1990. Pathways from the Periphery: The Politics of Growth in the Newly Industrializing Countries. Ithaca: Cornell University Press.

Haggard, Stephan, Byung-kook Kim, and Chung-in Moon. 1991. The Transition to Export-Led Growth in South Korea, 1954-1966. Journal of Asian Studies 50: 850-73.

Hong, Wontack. 1979. Trade, Distortions, and Employment Growth in Korea. Seoul: Korea Development Institute.

Horikane, Yumi. 2005. The Political Economy of Heavy Industrialisation: The Heavy and Chemical Industry (HCI) Push in South Korea in the 1970s. Modern Asian Studies 39: 36997.

Hughes, Helen, ed. 1988. Achieving Industrialization in East Asia. New York: Cambridge University Press.

IMF (International Monetary Fund). 1963. Korea: 1963 Article XIV Consultations. SM/63/97, October, Washington, DC.

IMF (International Monetary Fund). 1964. Korea-Exchange Reform. EBS/64/73, April 30. Washington.

IMF (International Monetary Fund). 1966. Korea: 1966 Article XIV Consultations. SM/66/108, September. Washington.

Jones, Leroy P., and Il SaKong. 1980. Government, Business, and Entrepreneurship in Economic Development: The Korean Case. Cambridge, MA: Harvard University Press.

Joo, Ik Jong. 2017. Revision of Korean Exchange Rate System in Early- and Mid-1960s. Review of Economic History 64: 161-88 [in Korean].

KDI (Korea Development Institute). 2016. The Korean Miracle. Seoul: Cengage Learning.

Kim, Chung-yum. 1994. Policymaking on the Front Lines: Memoirs of a Korean Practitioner, 1945-79. Washington: World Bank.

Kim, Chung-yum. 2011. From Despair to Hope: Economic Policymaking in Korea, 1945-1979. Seoul: Korean Development Institute.

Kim, Duol, and Heejin Park. 2021. Biological Living Standards of Korea During the PortOpening Period, 1876-1910. Journal of Economic History 81: 549-76. 
Kim, Hyung-A. 2004. Korea's Development Under Park Chung Hee. New York: Routledge. Kim, Joungwon Alexander. 1975. Divided Korea: The Politics of Development, 1945-1972. Cambridge, MA: Harvard University Press.

Kim, Kwang Suk. 1991a. The Interest-Rate Reform of 1965 and Domestic Saving. In Economic Development in the Republic of Korea: A Policy Perspective, ed. Lee-Jay Cho and Yoon Hyung Kim. Honolulu: University of Hawaii Press.

Kim, Kwang Suk. 1991b. Korea. In Liberalizing Foreign Trade: The Experience of Korea, the Philippines, and Singapore, Volume 2, ed. Demetris Papageorgiou, Michael Michaely, and Armeane M. Choksi. New York: Basil Blackwell.

Kim, Kwang Suk. 1991c. The 1964-65 Exchange Rate Reform, Export Promotion Measures, Import Liberalization Program. In Economic Development in the Republic of Korea: A Policy Perspective, ed. Lee-Jay Cho and Yoon Hyung Kim. Honolulu: University of Hawaii Press.

Kim, Kwang Suk. 2019. Dynamics of Industrial Policy I: Export-Oriented Industrialization, 9611971. In The Park Chung Hee Era: Economic Development and Modernization of the Republic of Korea, ed. Lee-Jay Cho. Honolulu: University of Hawaii Press.

Kim, Byung-Kook. 2011. The Leviathan: Economic Bureaucracy under Park. In The Park Chung Hee Era: The Transformation of South Korea, ed. Byung-Kook Kim and Ezra F. Vogel. Cambridge, MA: Harvard University Press.

Kim, Taehyun, and Chang Jae Baik. 2011. Taming and Tamed by the United States. In The Park Chung Hee Era: The Transformation of South Korea, ed. Byung-Kook Kim and Ezra F. Vogel. Cambridge, MA: Harvard University Press.

Kim, Pyŏng-guk, and Ezra F. Vogel. 2011. The Park Chung Hee era: The Transformation of South Korea. Cambridge: Harvard University Press.

Kim, Hyung-A, and Clark W. Sorenson, eds. 2011. Reassessing the Park Chung Hee Era, 19611979, ed. Hyung-A Kim and Clark W. Sorenson. Seattle: University of Washington Press.

Kim, Minho, Munseob Lee, and Yongseok Shin. 2021. “The Plant-Level View of an Industrial Policy: The Korean Heavy Industry Drive of 1973,” NBER Working Paper No. 29252, September.

Kimiya, Tadashi. 2011. The Cold War and the Political Economy of the Park Chung Hee Regime. In Reassessing the Park Chung Hee Era, 1961-1979, ed. Hyung-A Kim and Clark W. Sorenson. Seattle: University of Washington Press. 
Krueger, Anne O. 1979. The Developmental Role of the Foreign Sector and Aid: Studies in the Modernization of the Republic of Korea, 1945-1975. Cambridge, MA: Harvard University Press.

Krueger, Anne O., and Vernon W. Ruttan. 1989. Assistance to Korea. In Aid and Development, ed. Anne O. Krueger, Constantine Michalopoulos, and Vernon W. Ruttan. Baltimore, MD: Johns Hopkins University Press.

Krueger, Anne O., and Jungho Yoo. 2002. Chaebol Capitalism and the Currency-Financial Crisis in Korea. In Preventing Currency Crises in Emerging Markets, ed. Sebastian Edwards and Jeffrey A. Frankel. Chicago: University of Chicago Press.

Lane, Nathan. 2019. Manufacturing Revolution: Industrial Policy and Industrialization in South Korea. Unpublished manuscript, Department of Economics, Oxford University.

Lee, Hun-Chang, and Peter Temin. 2010. The Political Economy of Preindustrial Korean Trade. Journal of Institutional and Theoretical Economics 166: 548-71.

Lee, Steven Hugh. 2006. Development without Democracy: The Political Economy of US-South Korea Relations, 1958-1961. In Transformations in Twentieth Century Korea, ed. Yun-shik Chang and Steven Hugh Lee. New York: Routledge.

Lim, Phillip Wonhyuk. 2004. Path Dependence in Action: The Rise and Fall of the Korean Model of Economic Development. In History Matters: Essays on Economic Growth, Technology, and Demographic Change, ed. Timothy Guinnane. Stanford, CA: Stanford University Press.

Luedde-Neurath, Richard. 1986. Import Controls and Economic Development: A Reassessment of the South Korean Case. Boulder, CO: Westview Press.

Mason, Edward S., Mahn Je Kim, Dwight H. Perkins, Kwang Suk Kim, David C. Cole. 1980. The Economic and Social Modernization of the Republic of Korea. Cambridge, MA: Harvard University Press.

McDonald, Donald Stone. 1982. US-Korean Relations from Liberation to Self-Reliance. Boulder, CO: Westview Press.

Most, Amicus. 1966. History of Exports, 1964-1966. In Report on Program Management in USAID/Korea. Office of Export Development and Private Enterprise, United States Operations Mission to Korea. 
Most, Amicus. 1969. Expanding Exports: A Case Study of the Korean Experience. Washington: US Agency for International Development.

Nam, Chong-Hyun. 1995. The Role of Trade and Exchange Rate Policy on Korea's Growth. In Growth Theories in Light of the East Asian Experience, ed. Takatoshi Ito and Anne O. Krueger. Chicago: University of Chicago Press.

Park, Chung-Hee. 1963. The Country, the Revolution, and I. Seoul: Hollym.

Park, Tae-Gyun. 1999. Change in U.S. Policy toward South Korea in the Early 1960s. Korean Studies 23: 94-120.

Presidential Task Force on Korea. 1961. Report to the National Security Council, June 5. Available at www.jfklibrary.org/asset-viewer/archives/JFKNSF/127/JFKNSF-127-011. Rhee, Ki Jun. 2019. Institutional Reforms for National Economic Management. In The Park Chung Hee Era: Economic Development and the Modernization of the Republic of Korea, ed. Lee-Jay Cho. Honolulu: University of Hawaii Press.

Ryu, Sangyun, 2017. The Exchange Rate Reform under the Chang Myŏn Government. SaChong 92: 83-110 [in Korean].

SaKong, Il. 1993. Korea in the World Economy. Washington: Institute for International Economics.

Satterwhite, David Hunter. 1994. The Politics of Economic Development: Coup, State, and the Republic of Korea's First Five-Year Economic Development Plan (1962-1966). PhD thesis, University of Washington, Department of History, Seattle.

Shim, Theresa Y. 2010. Korea Inc.: Building Pre-Entrepreneurship in Korea. In Korean Entrepreneurship: The Foundation of the Korean Economy. New York: Palgrave MacMillan.

Steinberg, David I. 1982. Development Lessons from the Korean Experience: A Review Article. Journal of Asian Studies 42: 91-104.

Stern, Joseph J., J. H. Kim, Dwight H. Perkins, and J. B. Yoo. 1995. Industrialization and the State: Korean Heavy and Chemical Industry Drive. Seoul: Harvard Institute for International Development and Korea Development Institute.

US Comptroller General. 1962. Examination of Economic and Technical Assistance Program for Korea, International Cooperation Administration.

US Department of State. Report to Congress, Fiscal Years 1957-61. Washington. 
US Department of State. 1994. Foreign Relations of the United States, 1958-1960. Japan;

Korea, vol. XVIII. Washington: US Government Printing Office.

https:/history.state.gov/historicaldocuments/frus1958-60v18/d334.

US Department of State. 1964. Bulletin 50, May 25, Washington.

US House of Representatives. 1978. Investigation of Korean-American Relations, Part 6, July 19. Washington: Committee on International Relations.

Wade, L.L., and B.S. Kim. 1978. Economic Development of South Korea: The Political Economy of Success. New York: Praeger.

Westphal, Larry E. 1990a. Industrial Policy in an Export-Propelled Economy: Lessons from South Korea's Experience. Journal of Economic Perspectives 4: 41-59.

Westphal, Larry E. 1990b. Review of “Asia’s Next Giant: South Korea and Late Industrialization” by Alice H. Amsden. Journal of Economic Literature 28: 1735-36.

Westphal, Larry E., and Kwak Suk Kim. 1982. Korea. In Development Strategies in Semiindustrial Economies, ed. Bela Balassa. Baltimore, MD: Johns Hopkins University Press.

Woo, Jung-en. 1991. Race to the Swift: State and Finance in Korean Industrialization. New York: Columbia University Press.

Yoo, Jungho. 2017. Korea’s Rapid Export Expansion in the 1960s: How It Began. KDI Journal of Economic Policy 39: 1-23.

Yoo, Jungho. 2020. What Made Korea's Rapid Growth Possible? New York: Routledge. 